\title{
Prehistoric human presence on Mount Etna (Sicily), in relation to the geological evolution
}

\author{
Stefano Branca*,1, Francesco Privitera ${ }^{2}$, Orazio Palio ${ }^{3}$, Maria Turco ${ }^{4}$ \\ (1) Istituto Nazionale di Geofisica e Vulcanologia, Osservatorio Etneo-Sezione di Catania \\ (2) Museo Regionale di Catania, Dipartimento Beni Culturali, Regione Siciliana \\ (3) Dipartimento Scienze della Formazione, Università di Catania \\ (4) Soprintendenza per i Beni Culturali e Ambientali di Catania, Regione Siciliana
}

Article history: received March 28, 2021; accepted September 30, 2021

\begin{abstract}
This study analyses the relationship between the pre- and protohistoric sites on the slopes of Etna and the volcanic products, as well as the diverse settlement strategies in the different periods of prehistory. New C14 dating from significant excavations, in addition to those known from other Etnean sites, were performed with the aim of validating the chronology of the sequence of the different phases. A substantial concordance of the archaeological data with the volcanological ones has been found. It has been observed that a consistent human presence on Etna appears from the Middle Neolithic (5500 BC), after the sequence of eruptive events that marked the end of the Ellittico volcano (13550 - $13050 \mathrm{BC}$ ) and the formation of the Valle del Bove, and the subsequent debris and alluvial events on the eastern flanks of the volcano (7250 - $3350 \mathrm{BC}$ ). Human presence intensifies between the Late-Final Copper Age and the Early Bronze Age (2800 - $1450 \mathrm{BC}$ ), due to improvement in subsistence techniques and to the large presence of soils on lava flows suitable for sheep farming. The most recent phases of the Bronze Age are poorly represented, probably because of the concentration of the population in larger agglomerations (Montevergine and S. Paolillo at Catania, the Historical Hill at Paternò). The explosive eruptions taking place in this period seem to have had less impact on the settlement choices and have not affected the development of the sites over time.
\end{abstract}

Keywords: Etna volcano; Archeology; Human presence; Geological evolution; Eruptions.

\section{Introduction}

Starting from the second half of $18^{\text {th }}$ century, several authors sought to understand the correlations between ancient human evidence and the eruptive activity of Mount Etna. The subject has concerned, especially since the nineteenth century [e.g. the work of Recupero, 1815], the eruptions mentioned by historical sources and their attribution to the lava flows [Tanguy et al., 2007; 2012; Branca et al., 2015; 2016; Branca and Abate, 2019]. This research has produced several scientific works that have recently reached almost definitive results in the identification and examination of historical sources in relation to the phenomena described, highlighting the false eruptive events that over the centuries have been included in the numerous catalogues of eruptions [Guidoboni et 


\section{Stefano Branca et al.}

al., 2014].

Included in this context of interdisciplinary research are the relationships with archaeological stratigraphies, such as the study of the pyroclastic deposit of the 122 BC Plinian eruption [Coltelli et al., 1998] and subsequent identifications of the phenomenon in archaeological settings [Soraci, 2004; Privitera, 2018].

The idea of a cross-dating between eruptions and archaeological remains began to carry weight since it was clear that there was also a long period in Sicily and in the Etnean area preceding the oldest written sources, namely the prehistoric and protohistoric ages (in Sicily until the $8^{\text {th }}$ century BC), which, however, began to be revealed with scientific methods only after the arrival in Sicily, in 1888, of the archaeologist Paolo Orsi from Rovereto [La Rosa, 1985].

Already in the early $20^{\text {th }}$ century, the volcanologist De Fiore attempted to highlight the relationship between specific eruptive events and some archaeological sites, as in the case of the lava flow in Trefontane locality near Paternò [De Fiore, 1921]. Likewise, Paolo Orsi himself posed the problem of the relationship between a deposit of the Early Bronze Age inside the cave of Via Scutari in Biancavilla and the lava flow in which it was located, proposing, however, the impossible explanation of the superimposition of the flow to a pre-existing outdoor site [Orsi, 1930-31].

In the following decades, the relative chronological sequence of the prehistoric cultures of Sicily was clarified mainly by Luigi Bernabò Brea, in such a way as to later require only limited adjustments and clarifications (Table 1) [Bernabò Brea, 1958]. The absolute datings, instead, following the increase of radiocarbon datings, especially since the diffusion of the AMS technique, have undergone a general chronological backdating of the archaeological facies, compared to the traditional dates obtained by comparison and interpolation, especially for the periods preceding the $15^{\text {th }}$ century BC (in Sicily corresponding to the passage between Early and Middle Bronze Age).

Regarding the geological knowledge of Mount Etna, the main phases of the evolution of the eruptive activity have been defined on a stratigraphic and geochronological basis thanks to absolute dating with ${ }^{40} \mathrm{Ar}{ }^{39} \mathrm{Ar}$ methods [Branca et al., 2011b; De Beni et al., 2011]. Contextually, the realization of absolute datings of Holocene lava flows [Branca et al., 2015, 2019; Magli et al., 2021], has enabled the continuous updating of geochronological data reported in the Geological Map of Etna Volcano [Branca et al., 2011a].

This multidisciplinary stratigraphic, tephro-stratigraphic, and lava flow dating approach has already allowed us to update the relationship between historically known eruptions of the last 2700 years and lava flows recognized in the geologic record [Branca et al., 2011a; Tanguy et al., 2012; Branca and Abate, 2019].

In this context, therefore, a new and detailed comparison between geological and archaeological data is now extremely useful for the earlier periods (Figure 1), to clarify the settlement choices and the probable subsistence strategies of the people that settled on the slopes of Etna between the 6th and the 1st millennium BC (Table 1).

In fact, the study of human presence on Etna, in particular from the Neolithic to the beginning of the Iron Age $\left(6^{\text {th }}\right.$-early $1^{\text {st }}$ millennium $\left.\mathrm{BC}\right)$, takes account of the pedological and hydrographic characteristics, with particular reference to the morphology and chronology of the lava flows that constitute the slopes of the volcano. The altimetric distribution of the vegetation belts, that corresponds to different possibilities of occupation and land use [Poli et al., 1981; Poli, 1991], is also strongly influenced by the presence of lava flows that determine the different substrata on which the vegetation is implanted. In addition, it is very important to consider the location of springs, which are very rare and with a limited flow at medium and high altitudes, while they are abundant in areas in contact with sedimentary terrains [Branca and Ferrara, 2013].

In this paper, we present all the prehistoric stations in the Etna region known in literature, for which we have sufficient indications regarding the chronology and the topographic position, and their relationships with the volcanic succession defined in Branca et al. [2011a]. The literature data were increased by 10 new ${ }^{14} \mathrm{C}$ datings of bone or coal samples carried out for this study, which constitute important new data to update the frame of the relations between prehistoric human settlements and the evolution of Etna's eruptive activity.

It seemed useful to us to compile a table in which the sequence of the prehistoric periods identified in the southern part of the Italian peninsula and in Sicily is presented. The reported chronologies are sufficiently reliable and generally accepted because they are based on the absolute dates obtained in the last years and on the chronotypological sequences of the craft productions of the different prehistoric cultures (Figure 2). We will refer to these chronologies in this paper (Table 1). 
Prehistoric human presence on Mount Etna

\begin{tabular}{|c|c|c|c|c|}
\hline $\begin{array}{l}\text { Archaeological } \\
\text { phases }\end{array}$ & yrs BC & $\begin{array}{l}\text { Sicilian Archaeological } \\
\text { facies }\end{array}$ & Aegean & $\begin{array}{l}\text { Main volcanic } \\
\text { events }\end{array}$ \\
\hline Upper Paleolithic & $15000-9.000$ & Epigravettian & & $\begin{array}{l}\text { Ellittico Plinian } \\
\quad \text { eruptions; } \\
13550-13050 \mathrm{BC}\end{array}$ \\
\hline Mesolithic & $9000-6200$ & Mesolithic & & $\begin{array}{l}\text { Initial stage of Valle } \\
\text { del Bove formation } \\
\text { (Milo debris flow); } \\
7250 \text { BC }\end{array}$ \\
\hline Early Neolithic & $6200-5700$ & Archaic Impressed Pottery & EN & $\begin{array}{c}\text { Debris and alluvial } \\
\text { phenomena, } \\
\text { (Chiancone deposit); } \\
\text { from } 6450 \text { to } 3350 \mathrm{BC}\end{array}$ \\
\hline Middle Neolithic I & $5700-5200$ & $\begin{array}{l}\text { Stentinello } 1 \text {; only impressed } \\
\text { pottery }\end{array}$ & LN I a & \\
\hline Middle Neolithic II & $5200-4500$ & $\begin{array}{l}\text { Stentinello } 2 \text {; impressed and } \\
\text { painted pottery }\end{array}$ & LN I a & \\
\hline Late Neolithic I & $4500-4300$ & Serra d'Alto, Early Diana & LN I b & \\
\hline Late Neolithic II & $4300-4000$ & Classic Diana & LN I b & \\
\hline Final Neolithic & $4000-3700$ & Final Diana-Spatarella & LN II a & \\
\hline Early Copper Age & $3700-3300$ & $\begin{array}{l}\text { Spatarella, S. Cono-Piano } \\
\text { Notaro; Early Piano Conte }\end{array}$ & LN II b & \\
\hline Middle Copper Age & $3300-2800$ & Piano Conte; Serrafercchio & EBA I & \\
\hline Late Copper Age & $2800-2350$ & $\begin{array}{c}\text { Malpasso; Piano Quartara, } \\
\text { Bell Beaker }\end{array}$ & EBA II & \\
\hline Final Copper Age & $2350-2200$ & $\begin{array}{l}\text { Zungri, S. Ippolito; } \\
\text { Pellegriti-Marca }\end{array}$ & EBA III & \\
\hline Early Bronze Age 1 & $2200-1800$ & Castelluccio & EBA III-MBA I & $\begin{array}{c}\text { Sub-Plinian Eruption } \\
1980 \pm 60 \mathrm{BC}\end{array}$ \\
\hline Early Bronze Age 2 & $1800-1450$ & Castelluccio & MBA II-LBA I-II & \\
\hline Middle Bronze Age & $1450-1270$ & Thapsos & LBA III A-B1 & $\begin{array}{l}\text { Vulcanian eruption } \\
\qquad 1200 \pm 60 \mathrm{BC}\end{array}$ \\
\hline Late Bronze Age & $1270-1150$ & Pantalica I-II & LBA III B & \\
\hline Final Bronze Age & $1150-1050$ & Pantalica II, Cassibile & $\begin{array}{l}\text { LBA III C / sub- } \\
\text { Mycenaean }\end{array}$ & \\
\hline
\end{tabular}

Table 1. Chronological sequence of the archaeological phases of the Sicilian prehistory compared with the main volcanic events of Etna of the investigated period. 


\section{Stefano Branca et al.}

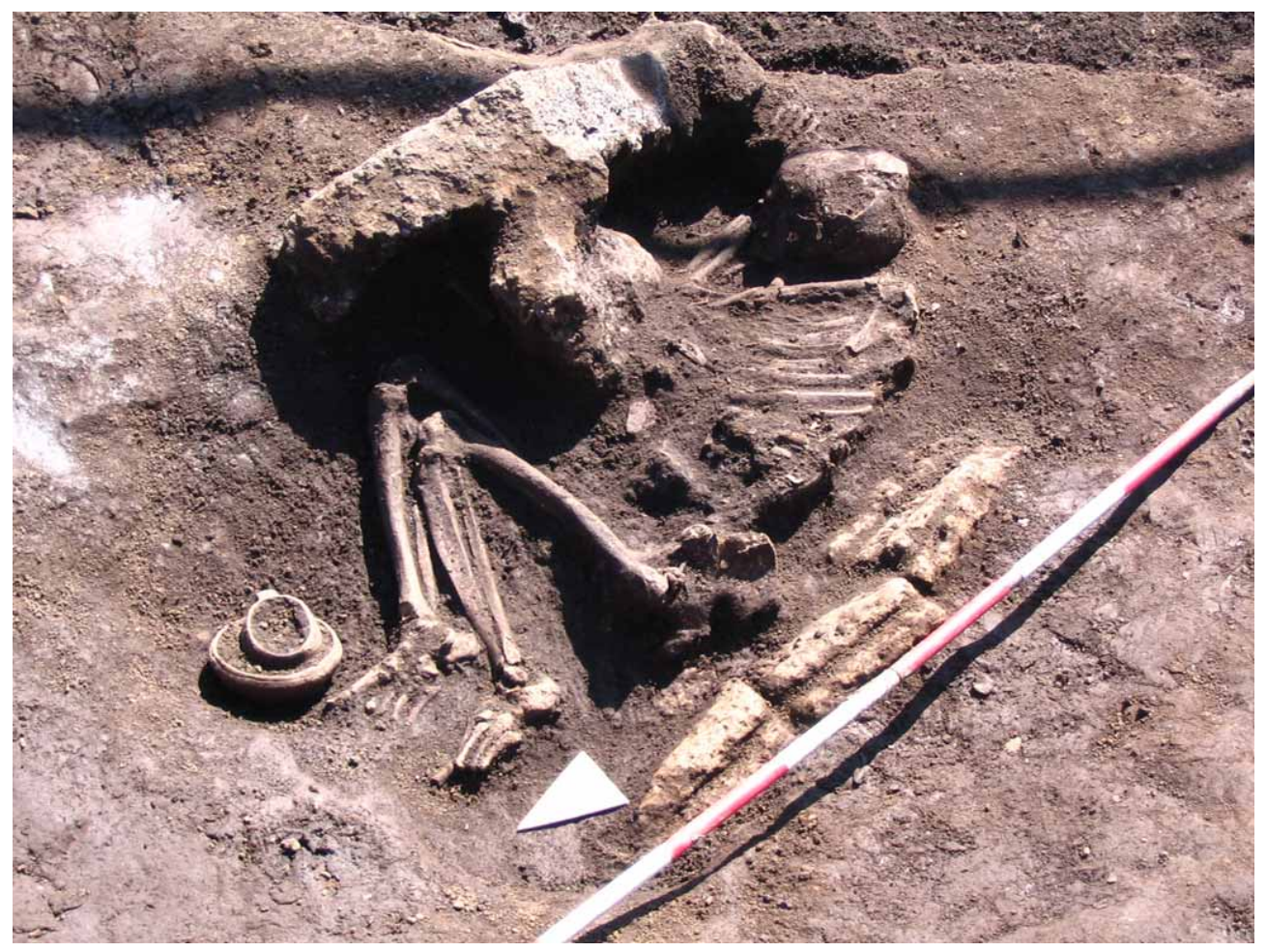

Figure 1. The human presences on Etna volcano. Detail of a tomb of the final Neolithic Necropolis of Balze Soprane in the lower north-west flank (tomb 3 after Lisi et al. [2012]) located on a lava flow dated between 32 and 42 ka BP [Branca et al., 2011a].

\section{Geological framework of Etna volcano}

The geological evolution of Etna volcano is divided into four main phases by Branca et al. [2011b] according to geochronological data [De Beni et al., 2011] named: Basal Tholeiitic, Timpe, Valle del Bove and Stratovolcano (Figure 3). The oldest volcanics of Etna region (Basal Tholeiitic phase) are related to submarine eruptions occurring around $500 \mathrm{ka} \mathrm{BP}$, outcropping on the coastal cliff of the Aci Castello Castle Rock and inland between the villages of Ficarazzi and Aci Trezza. In this area, pillow lavas, hyaloclastic pillow-breccia and shallow subvolcanic bodies are interlayered in the sedimentary basement consisting of Early-Middle Pleistocene marly clays. Following this submarine eruptive activity, a long hiatus elapsed during which the regional uplift produced the gradual emergence of the Quaternary sedimentary deposits. The earliest sub-aerial lava flows of Etna region are dated back to about $330 \mathrm{ka}$ BP forming a wide and thin lava plateau, extending for more than $25 \mathrm{~km}$ along the western periphery of the Etna edifice. These lava flows crop out discontinuously between the towns of Adrano and Paternò along the left bank of Simeto river valley, forming several terraced bodies developed both on the old alluvial plain of the Simeto River and on the sedimentary terrains of the Appenninic-Maghrebian Chain [Branca et al., 2011a].

In the geological record of Etna volcanic succession, a hiatus of about 100 ka separates the Basal Tholeiitic phase from the following one, the so-called Timpe phase. In fact, between 220 and $121 \mathrm{ka} \mathrm{BP,} \mathrm{the} \mathrm{effusive} \mathrm{activity} \mathrm{was}$ concentrated mainly along the Ionian coast where fissure-type eruptions built an earlier volcano structure in the Etna region, ascribable to a lava-shield elongated NNW-SSE for at least $22 \mathrm{~km}$. The lava succession of this phase is currently exposed mainly along the fault scarps of the Timpe system at Acireale and Moscarello up to the Ripe della Naca fault (Figure 3). In this period, scattered effusive eruptions also took place in a wide area corresponding to the present lower SW and SE flanks of Etna. Furthermore, the eruptive activity about $129 \mathrm{ka}$ BP shifted westward at the end of this phase, for the first time, toward the central region of the volcano that corresponds to the present-day Val Calanna-Moscarello area. Fissure eruptions occurred until about $112 \mathrm{ka}$ BP in the south-eastern lower flank in the Valverde area. 


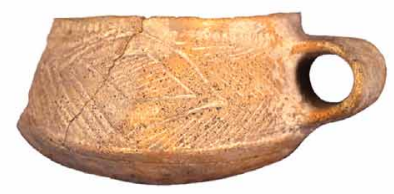

1

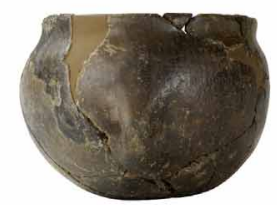

5

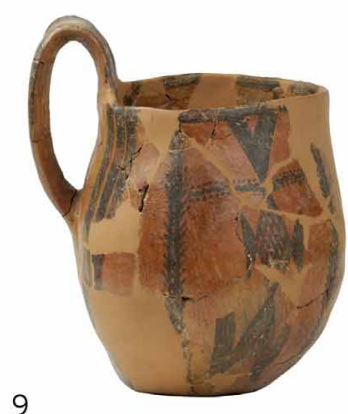

9

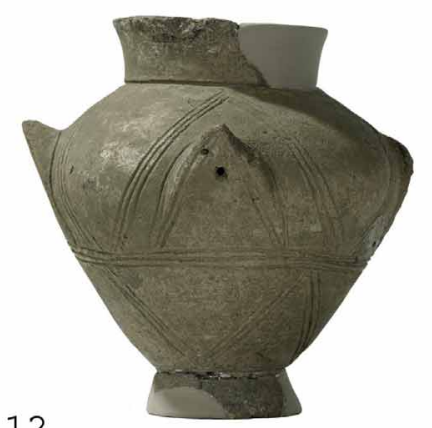

2
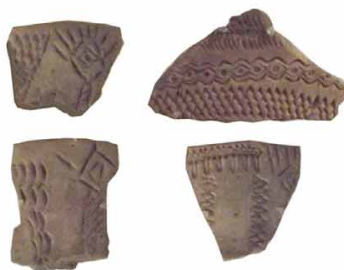

$-m$

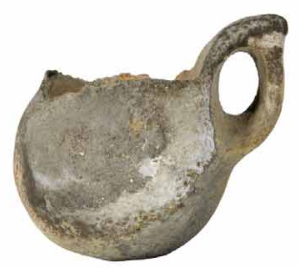

6

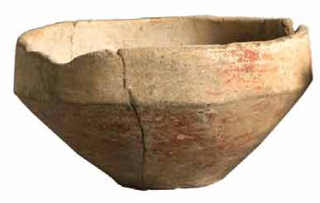

3

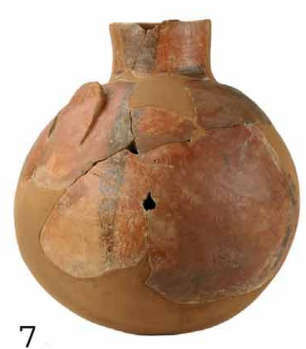

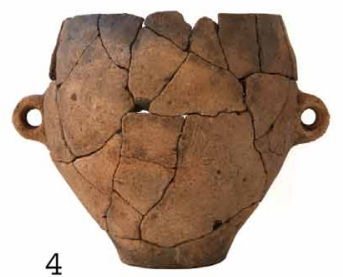

4

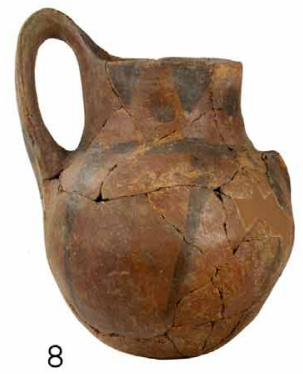

10

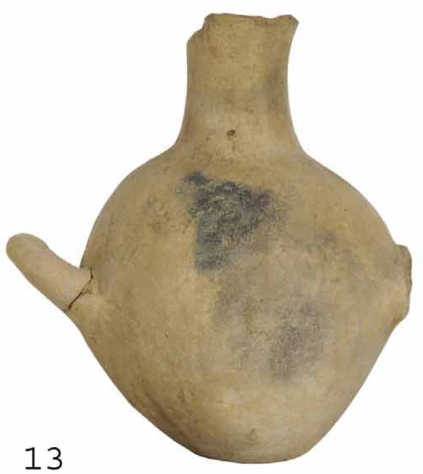

11
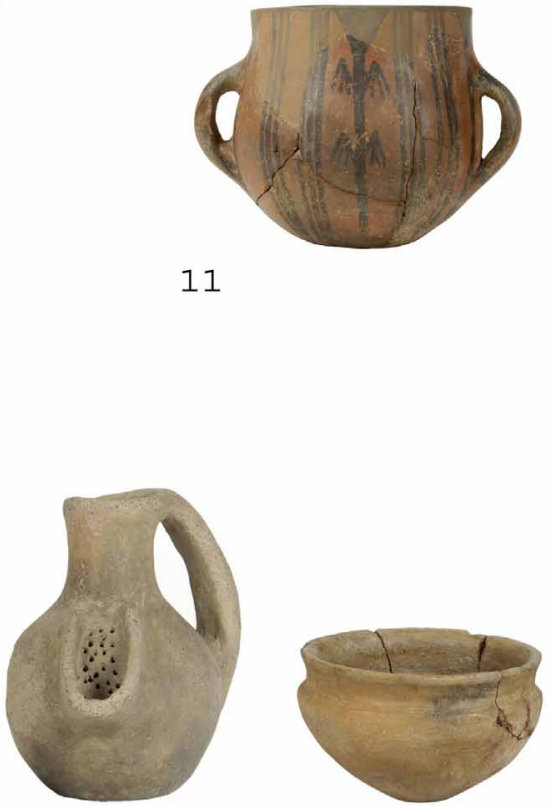

Figure 2. 1) Middle Neolithic cup from the tomb of Fontanazza (Adrano) (after Lamagna and Neri [2015]); 2) Middle Neolithic ceramic fragments from the Adrano area (Archeological Museum at Adrano); 3) Final Neolithic Cup from the tomb of Biancavilla (after Lamagna and Neri [2015]); 4) Final Neolithic bowl from fire structure of Balze Soprane, Bronte (after Palio and Turco [2015]); 5) Early Copper Age bowl from Petralia Cave (after Privitera and La Rosa [2007]); 6) Late copper age bowl from Basile Cave, Catania (after Privitera and La Rosa [2007]); 7) Final Copper Age jug from Pellegriti Cave, Adrano (after Privitera and La Rosa [2007]); 8) Final Copper Age jug from Petralia Cave, Catania (after Privitera and La Rosa [2007]); 9) Early Bronze Age jug from Petralia Cave, Catania (after Privitera and La Rosa [2007]); 10) Early Bronze Age pedestal cup from Sapienza Deposit, Adrano (after Privitera and La Rosa [2007]); 11) Early Bronze Age bowl from Pietralunga Cave, Adrano (after Privitera and La Rosa [2007]); 12) Middle Bronze Age bowl from the hut of Barriera, Catania (after Privitera and La Rosa [2007]); 13) Late Bronze Age vessels from tomb 1 of S. Marco, Paternò (Cortesy of L. Maniscalco). 


\section{Stefano Branca et al.}

During the third phase, named Valle del Bove, the shifting of the magma feeder system in the present Valle del Bove area and the beginning of the central-type volcanism took place with the formation of several small polygenic stratocones that were active between at least $110 \mathrm{ka}$ and $60 \mathrm{ka}$ (Figure 3). In particular, these volcanoes were characterized by explosive and effusive activity that led to the construction of the earlier stratovolcano structure in Etna region, reaching a maximum elevation of about $2600 \mathrm{~m}$ (Cuvigghiuni volcano) [Branca et al., 2011a, b].

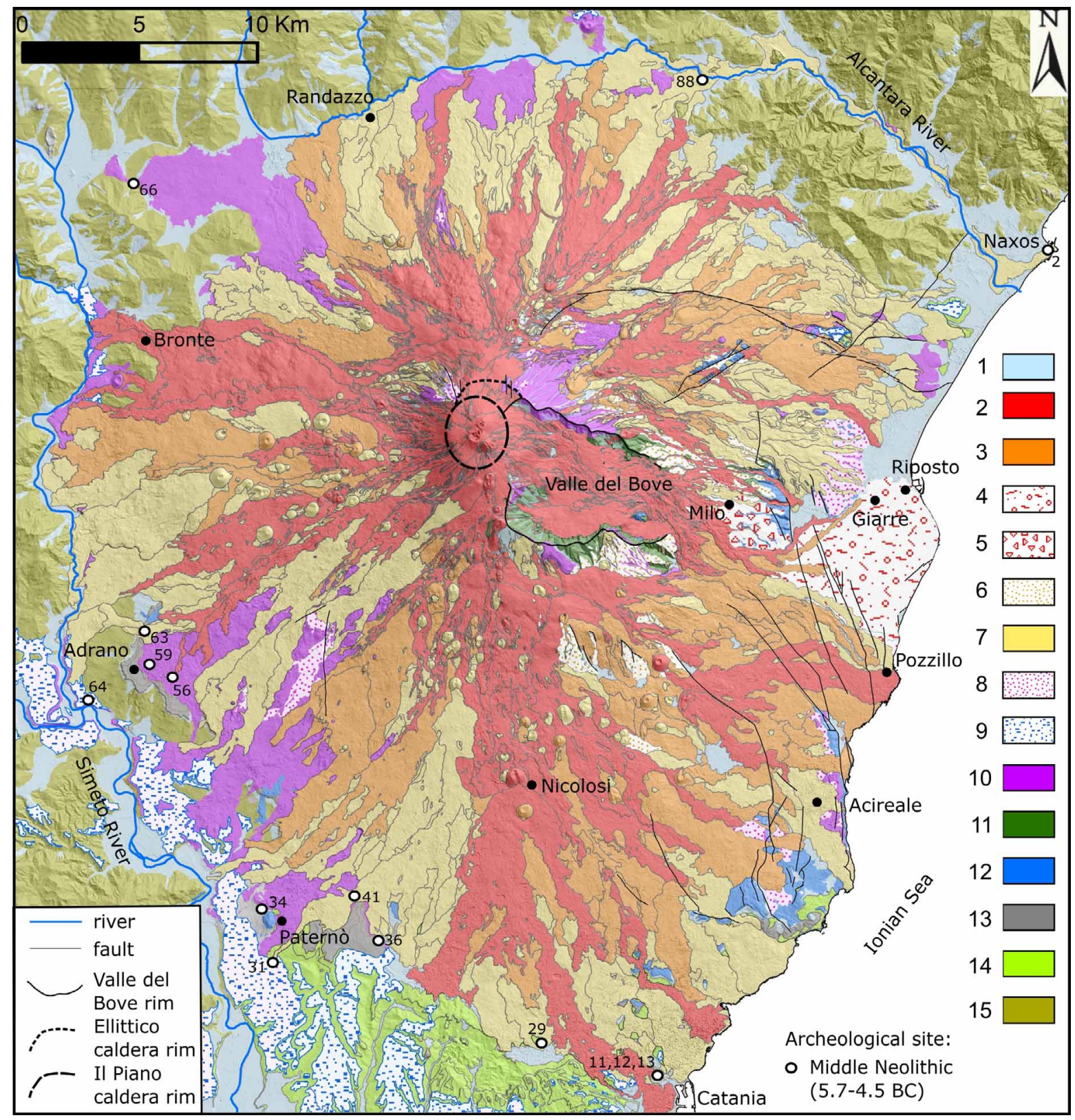

Figure 3. Geological map of Etna volcano modified from Branca et al. [2011a] with the location of the archeological sites of Middle Neolithic Age (5700-4500 yrs BC). Legend of the map: 1) present and recent alluvial deposits; Stratovolcano phase-Mongibello volcano: 2) volcanic products 122 BC-present (Torre del Filosofo formation); 3) volcanic products 3.9 ka BP-122 BC (Pietracannonne upper member formation); 4) Milo debris flow; 5) Chiancone deposit; 6) Cubania pyroclastic succession; 7) volcanic products 15-3.9 ka BP (Pietracannonne lower member formation); Stratovolcano phase-Ellittico volcano: 8) pyroclastic succession; 9) old terraced alluvial deposits; 10) volcanic products 60-15 ka BP; 11) volcanic products of the Valle del Bove phase (110-65 ka BP); 12) volcanic products of the Timpe phase (220-110 ka BP); 13) volcanic products of the Basal Tholeiitic phase (500 and 330 ka BP); 14) sedimentary Quaternary deposits; 15) Apenninic-Maghrebian Chain. 
The complex volcanic succession of this phase is exposed in the southern wall of the Valle del Bove and along the eastern portion of the northern one down to the Moscarello area, consisting mainly of an alternation of lava flows, autoclastic lavas, pyroclastic and epiclastic deposits.

The Stratovolcano phase combines the products of the Ellittico and Mongibello volcanoes erupted between about $60 \mathrm{ka}$ and the present. In particular, Ellittico volcano activity began about $60 \mathrm{ka}$ BP $4 \mathrm{~km}$ northwestward of the previous Valle del Bove volcanoes and was characterized by both explosive and effusive activity from summit vents and flank fissures. The emplacement of wide lava flow fields by flank fissures generated the gradual expansion of Ellittico slopes on the sedimentary terrains between about 40 ka and $30 \mathrm{ka}$ BP (Piano Provenzana formation) [Branca et al., 2011a]. The growth of the Ellittico volcano flanks caused a radical modification of the hydrographic setting on the northern margin of the volcano edifice about 30-25 ka BP as a consequence of the lava flows filling the paleo-Alcantara valley, producing a northward stream diversion of the paleo-Alcantara riverbed into the present day valley [Branca and Ferrara, 2001, 2013; Branca, 2003]. In the same period, flank eruptions at low altitudes along the western flank of Ellittico volcano allowed lava flows to flood the Simeto river valley between $40 \mathrm{ka}$ and $20 \mathrm{ka}$ $\mathrm{BP}$, causing repeated dam phenomena of the paleo-watercourse. Flank eruptions along the eastern flank produced lava flows that reached the Ionian coast near Fondachello and Acireale around $30 \mathrm{ka}$ BP (Figure 3). Overall, about $20 \mathrm{ka}$ BP the Ellittico volcano reached the elevation of about $3600 \mathrm{~m}$ a.s.l. and the maximum areal expansion with a maximum diameter of about $45 \mathrm{~km}$ that corresponds to the diameter of the Etna edifice today. Ellittico volcano activity ended around 15.5-15 ka BP with four caldera-forming plinian eruptions [Coltelli et al., 2000; Del Carlo et al., 2017] that formed a wide summit caldera.

During the post- $15 \mathrm{ka} \mathrm{BP}$, the almost persistent basaltic volcanic activity formed the Mongibello volcano through summit and flank eruptions whose products cover about $88 \%$ of Etna's surface. The stratigraphy of the widespread Mongibello lava flows succession was reconstructed thanks to the presence of several Holocene tephra marker beds that were used for stratigraphic correlation and relative dating of lava flows [Coltelli et al., 2000 and Branca et al., 2011a]. In particular, according to Branca et al. [2011a] the Mongibello lava succession was grouped in the Pietracannone formation covering $54 \%$ of the Etna edifice that was divided in two members (lower and upper) on the basis of a lithohorizon represented by the FS tephra marker bed (Figure 4) dated $3960 \pm 60$ years BP [Coltelli et al., 2000, 2005]. In this time span, the flank eruptions occurred from vents located according to three main magma intrusion zones of the volcano edifice, the NE, S and W rifts [Azzaro et al., 2012]. Lava flows generated by fissures located at lower elevations reached the periphery of the volcano edifice, modifying the morphological setting of the Ionian coast, of the Alcantara valley and of the Simeto river floor, superimposing on the Ellittico lava flows. During the first stage of Mongibello activity, the morphostructural setting of the volcano edifice was radically modified 9270-9250 yr BP [Branca et al., 2016] by gravitational slope failures and subsequent erosive phenomena that involved a large portion of the eastern flank, generating the wide depression of the Valle del Bove. The volcaniclastic deposits associated with these slope failures crop out immediately eastward of the Valle del Bove down to the coast. They are represented by the Milo debris avalanche deposit and by a wide fan-shape debris-alluvial deposit, locally named "Chiancone" [Branca et al., 2011a and references within]. Mongibello volcano activity was also characterized by explosive eruptions from the summit crater that produced a Holocene pyroclastic succession outcropping on the eastern flank [Coltelli et al., 2000; Del Carlo et al., 2004]. In particular, the Holocene explosive activity consists of several strombolian to subplinian events whose pyroclastic fall deposits are mainly distributed on the eastern flank (Figure 4). In the last 4000 years, two of the main Holocene explosive eruptions from the summit crater occurred at $3960 \pm 60$ years BP [FS tephra layer of Coltelli et al., 2000, 2005 in Figure 4] and at $3150 \pm 60$ years BP [FL tephra layer of Coltelli et al., 2000 in Figure 4]. The FS scoria fall deposit is the most widespread tephra outcropping in the east flank, indicating a subplinian intensity for this eruption and the FL tephra consists of both pyroclastic fall and flow deposits dispersed in the NE flank interpreted as produced by a vulcanian eruption [Del Carlo et al., 2004].

In historical time, the largest explosive eruption of Holocene time occurred in 122 BC [Coltelli et al., 1998]. The 122 BC Plinian eruption produced a widespread pyroclastic fall deposit on the southeast flank of Etna and caused huge damage to the ancient town of Catania (Figure 4). The dangerous effects of this event on the buildings and on the social and economic life of the Roman town are reported in two Greek and six Roman sources [Guidoboni et al., 2014]. This eruption was associated with the formation of a summit caldera, named Cratere del Piano, located at 2900 $m$ a.s.l. [Azzaro et al., 2012]. The eruptive activity post-122 BC produced the filling of the Cratere del Piano caldera, building the present Etna summit cone and the lava flows generated by flank eruptions covered $34 \%$ of the volcano edifice (Torre del Filosofo formation) [Branca et al., 2011a]. 


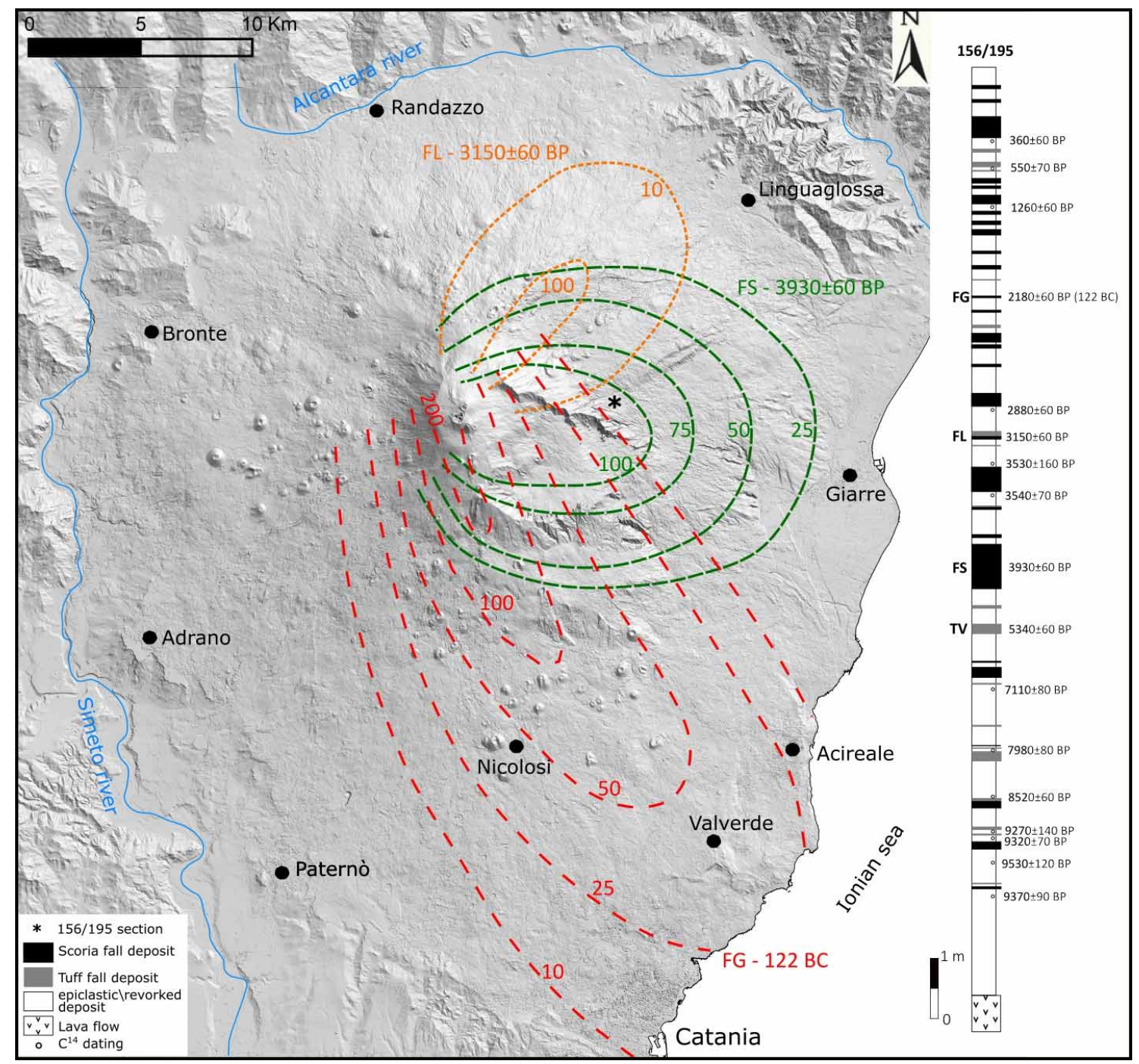

Figure 4. Areal distribution and thickness in centimeters of the pyroclastic deposits of the main explosive eruptions of Holocene time occurring on Etna [modified from Coltelli et al., 2000] and location of the tephrostratigraphic section n. 156/195 where the most preserved pyroclastic succession of Etna is exposed [modified from Del Carlo et al., 2004]. Letters indicate the code of the main tephra marker beds recognized in the Holocene pyroclastic succession by Coltelli et al. [2000].

\section{Pre- and protohistoric human settlement on Etna: distribution and chronology}

Table 2 in Appendix reports all the prehistoric sites of the Etna region known in the archaeological literature, for which the position has been identified precisely or approximately so as to link them to the lava flows of Etna. In the table the sites, indicated by a progressive numbering, are topographically ordered starting from the Ionian coast, in a clockwise direction. The name of the sites, their nature (settlement, necropolis, area of fragments), position, chronology, and the lava flow to which they are connected, are reported. For several sites, which will be appropriately indicated, the data, especially the topographical ones, may have a greater component of uncertainty. They are in fact excavations or discoveries dating back to more than a century ago, for example in the quarter of Barriera at Catania [Orsi, 1907] or in the territory of Paternò [Cafici, 1914] or, especially for the area of Adrano, casual discoveries on the soil or within caves. These have also been amply illustrated under the aspect of the objects found in places indicated only by the name of the countryside or by the one of the landowners. After several decades, 
these factors created many difficulties to identify the sites, considering the transformations that the territory has been undergone in the present era.

Evidence related to the Upper Palaeolithic and Mesolithic periods (30,000-10,000 BC: see Table 1) is lacking on Etna. Conversely, highland sites on both the Madonie (Mt. dei Cervi) and Nebrodi (Riparo della Rocca di S. Marco) mountains, both above $1000 \mathrm{~m}$ a.s.l., were frequented during that age [Baldini et al., 1976; Bernabò Brea, 1965; Recami et al., 1983]. We must presume that on Etna there were hunting areas too, such as the present marshy area of Lake Gurrida, which, however, is of recent formation since it was generated during a flank eruption in the 10th century AD producing a lava flow [Murazzo Rotto dated 950 $\pm 30 \mathrm{AD}$ in Branca et al., 2011a], that caused the damming of the Flascio River.

The Palaeolithic stations known for this area are instead limited to the Simeto valley, on its hydrographic right bank, except for the shelter of the Saragoddio locality, on the left bank, south of the Bronte urban center (Table 2, n. 72), where tools attributed to the Mesolithic (between the $10^{\text {th }}$ and $7^{\text {th }}$ millennium BC: see Table 1) were collected [Cultraro 2007]. In this period, the main volcanic events are related to the sequence of Plinian eruptions occurring in a short period around 13550-13050 BC. It marked the end of the Ellittico volcano activity, producing widespread pyroclastic fall deposits in the east, southeast and north flanks and pyroclastic flow deposit in the southwest flank [Coltelli et al., 2000; Del Carlo et al., 2017], as well as a catastrophic flank collapse that involved the eastern flank of the Etna edifice, producing the wide depression of the Valle del Bove. All this deeply modified the morphological setting of this portion of the territory up to the Ionian coast. In particular, the formation of the Valle del Bove is the result of a series of coalescing landslides started in about $7250 \mathrm{BC}$ with the emplacement of the Milo debris flow, followed by further enlargements of the valley southward. These enlargements generated a succession of debris and alluvial deposits between about $6450 \mathrm{BC}$ and $3350 \mathrm{BC}$ that modified the morphological setting of the Ionian coast between Pozzillo and Riposto covering an area of about $40 \mathrm{~km}^{2}$ (Chiancone deposit) [Calvari et al., 1998, 2004]. The formation of such a large alluvial fan was probably favored by the strong increase in erosion, transport and deposition processes at the end of the Last Glacial Maximum.

It is evident, therefore, that during the Upper Palaeolithic period (15000-10000 BC) and the Mesolithic period (10000-6300 BC), the conditions on Etna were not favorable to human settlement, particularly on the eastern slope, where finds are scarce even for later prehistoric phases. Also the Early Neolithic (6500-5500 BC), the first moment of diffusion of some agricultural and pastoral practices, is only very slightly represented in terms of findings, with the probable exception of S. Marco di Paternò, in an area at the edge of the Etnean edifice. More generally, the extent of the areas affected by lava flows of late prehistoric and historical period, which have erased any traces of these more ancient periods, also needs to be considered.

Quite different was the occupation of the Etnean region during the Middle Neolithic, from 5500 to $4500 \mathrm{BC}$ (Figure 3), based on the village economy, with cultivation of cereals and legumes and breeding mainly of sheep and goats. Regarding the craft production, this phase is characterized by the diffusion of impressed pottery of the Stentinello style (Figure 2. 1-2), named after the village excavated by Orsi near Syracuse [Orsi, 1890], and by the production of polished basalt stone tools (Table 1). Most of the outdoor sites, in which the few excavations did not reveal certain traces of huts, present instead in other areas of Sicily, are close to the coast on the eastern (Naxos and Calatabiano, n. 2, 3) and southern flanks (Catania, n. 11, 12, 13); on the other flanks, they were found either near the rivers (S. Domenica di Castiglione, in the Alcantara valley, n. 88, or the numerous sites in the Simeto valley, Trefontane or S. Marco, near Paternò, nos. 31, 34, or Fontanazza, near Adrano, n. 64), or in the lower southwest slope. In any case, for the most part, they lie close to the springs in the area of contact between volcanic and sedimentary terrains (the numerous sites of Belpasso (n. 36-41), and in the urban area of Adrano (n. 56, 59). In all these cases, the soils are quite loose and lie on alluvial deposits or are the result of disintegration and humification of particularly ancient lava flows, referable to the Timpe or Basal Tholeiitic phases, and, in some cases, on Ellittico lavas. Only a part rests on lavas of the Pietracannone Formation, lower Member, dating back less than 15000 years BP, such as, for example, the rich settlement of Valcorrente (Belpasso), or the hill of Montevergine, in the urban area of Catania (Barriera del Bosco lava flow recently dated: 11234-10941 BP and 8395-8236 BP) [Magli et al., 2021], uninterruptedly occupied from the 6th millennium to the present day, which however is located near a seaport with a considerable water availability. In the hilly areas there is also sporadic evidence of the frequentation of some caves, for purposes still not clear (Pezzamandria di Misterbianco, n. 29; Balze Soprane II di Bronte, n. 66).

During the Late-Final Neolithic periods (4500-3700 BC: Figure 5), characterized by the lustrous red-surface pottery of Diana style (Figure 2.3-4), some sites near the rivers and coasts continued to be frequented (Naxos or the 


\section{Stefano Branca et al.}

hill of Montevergine: n. 2, 15). In the latter, among other things, a cist tomb from this period was found [Privitera, 2010; Cultraro, 2014; Nicoletti, 2015]. Important sites, previously uninhabited, probably village locations, are attested along the Simeto valley, for example Tabana and Burello-Zarbo (n. 50) [Recami et al., 1983; Maniscalco, 2009], and, on the coast, at Capo Mulini (n. 8). This site, now about $6 \mathrm{~m}$ a.s.l., at that time must have been even closer to the sea, as documented by marine fossils located at $3 \mathrm{~m}$ a.s.l., dated to $4454 \pm 24 \mathrm{BP}$ (about $2500 \mathrm{BC}$ ) [Branca et al., 2014]. The occupation of the volcanic terrace, on which the centers of Adrano and Biancavilla lie (n. 47, 57, 58), continued also during the Late Neolithic period.

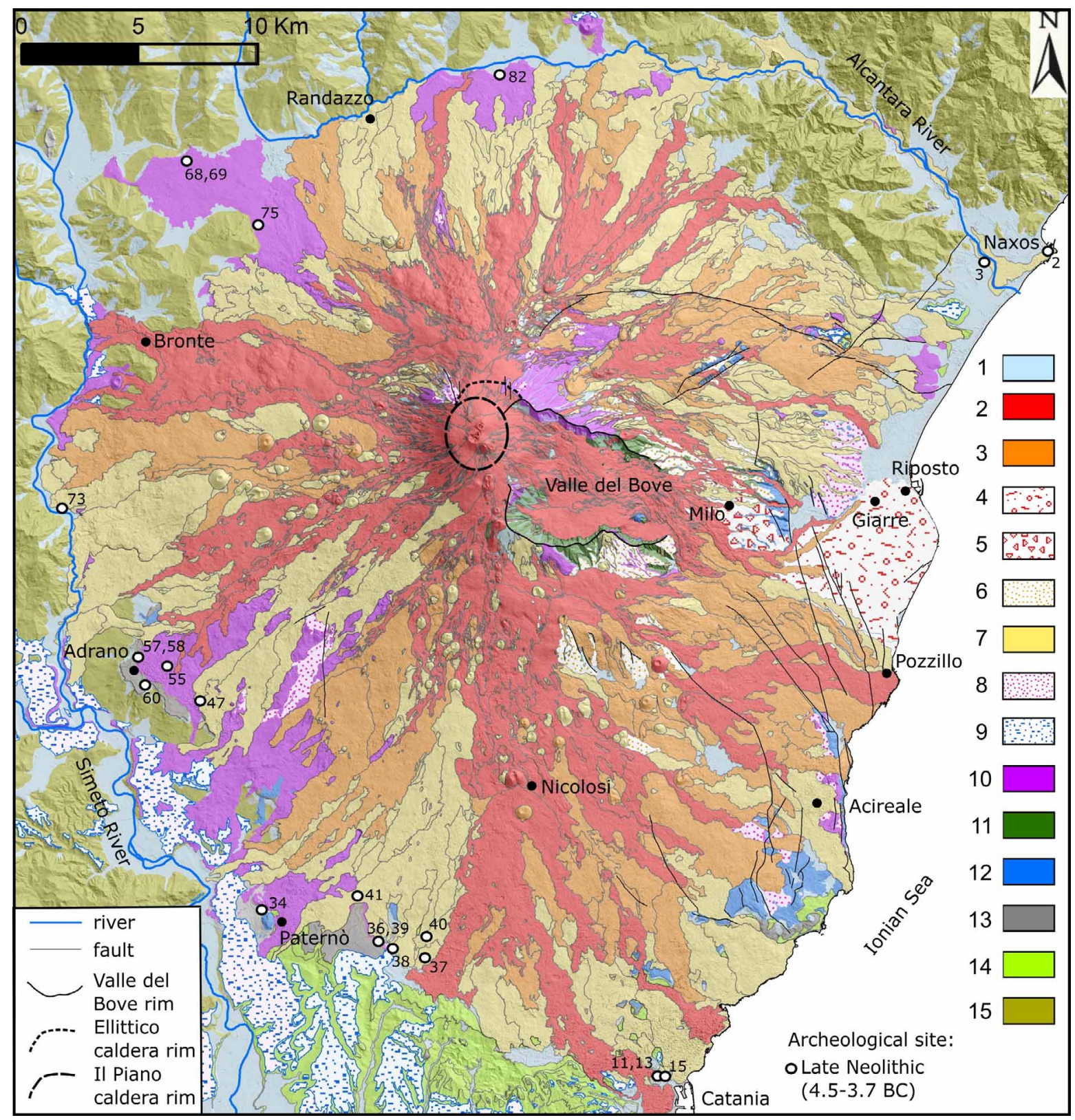

Figure 5. Geological map of Etna volcano modified from Branca et al. (2011a) with the location of the archeological sites of Late and Final Neolithic Age (4500-3700 yrs BC). For the legend of the map see Figure 3.

The existence of sites has recently been reported also in the Alcantara valley (S. Teodoro, near Randazzo: n. 82), and in the alluvial plain near the mouth of the Fiumefreddo river (Pianotta locality, Calatabiano), at the foot of a sedimentary hill, named Serra San Biagio. 
In the same period, areas at higher altitudes also began to be inhabited, especially in the saddle between the Simeto and Alcantara rivers. The vast lava field of the so-called "Sciare di S. Venera", 800-900 m a.s.l., dated about 40,000 years ago [Branca et al., 2011 a], was the site of a settlement to which is connected the necropolis with pit tombs and a structure with double circular pit probably for combustion (n. 68-69); moreover, in the whole plateau, especially in the area named Balze Soprane, were collected many Late Neolithic pottery fragments, that suggest the extensive, perhaps periodical, occupation of the area. Together with the pedological characteristics of the surface, with numerous pressure ridges $\backslash$ tumuli and limited areas of deep soil filling the cavities; these elements suggest a mixed economy, agricultural and pastoral, in which hunting may also have played a significant role. Recent surveys discovered fragments, dated from Middle Neolithic to Middle Bronze age (n. 40 and 41) [Arrabbito and Muratore, 2020], on the lava flows of Contrada Vignale and Mt. San Leo in the southwest flank, have enabled better defining their stratigraphic attribution to the lower member of Pietracannone formation compared to Branca et al. [2011a].

It should be noted that there is also a cave at a slightly higher altitude that could have been a temporary shelter (Tartaraci Cave: $\mathrm{n}$ 75). Another cave with traces of Late Neolithic frequentation is the Maccarrone Cave at Adrano (n. 55). It seems, therefore, that livestock breeding, probably sheep, began to acquire importance within the subsistence activities of these human groups [Lisi et al., 2009].

The Early Copper Age period is apparently almost absent in the Etna region (Figure 6), except for the Montevergine hill at Catania, which is also the only site with ${ }^{14} \mathrm{C}$ dates, from the excavation of via Teatro Greco (n. 12), which have dated this period to the beginning of the $4^{\text {th }}$ millennium BC [Nicoletti, 2015]. Radiometric dating for the rest of the 4th millennium is currently lacking in the entire Etna area. On the other hand, only a few sporadic ceramic fragments with engraved decoration of the so-called S. Cono-Piano Notaro style (Table 1), traditionally attributed to this phase, were found on the slopes of Etna (e.g. the locality of Marotta near Bronte: n. 73). One hypothesis is that of an extensive anthropic abandonment of the areas around the volcano. This abandonment could be explained by a gradual drying of the area, a phenomenon that would seem to have affected the central and eastern Mediterranean during the $4^{\text {th }}$ millennium, and increased around the middle of the $3^{\text {rd }}$ millennium BC [Sadori et al., 2013; Finné et al. 2011]. It does appear, however, to have had some influence on human population in other areas of Sicily [Giannitrapani, 2020a]. Regarding possible paroxysmal activities of Etna, apart from flank eruptions that may have occurred between 6000 and 5000 years ago [Branca et al., 2011a], it does not appear that the documented explosive eruption affected all slopes of the volcano with the same intensity [Coltelli et al., 2000; Del Carlo et al., 2004]. In fact, a coal fragment from Petralia Cave (n. 22: 3954-3788 cal BC) has been dated to this same era, but it cannot be linked to any archaeological context found within the cave itself, except perhaps to a single vessel from the facies of Piano Conte, the beginning of which in northern Sicily is dated to around 4000 BC [Martinelli, 2013] (Figure 2.5).

Therefore, rather than an extensive depopulation that would have affected the entire Etnean area, it is fair to assume that, in this part of Sicily, the characteristic craft productions of the previous Final Neolithic period (facies of Diana-Spatarella), continued even during the Early Copper Age. This hypothesis would also seem to be supported by the absolute dates associated in other areas of the island with the S. Cono-Piano Notaro style productions [Giannitrapani, 2020b for central Sicily; Gullì and Terrasi, 2020 for the Agrigento area] and with Diana-Spatarella in some contexts of our area, for example S. Marco at Paternò (n. 34) [Maniscalco, 2000] and the same Catania site (n. 12) [Nicoletti, 2015].

The Late-Final Copper Age and the Early Bronze Age periods (2800-1450 BC) traditionally distinguished according to the different style of ceramic productions (Figures 2.7-11), could be considered together since in many sites a significant continuity between the two moments is evident. Examples, in this sense, seem to be the Petralia Cave at Catania (n. 22) [Privitera, 2007a], the Pietralunga and Maccarrone caves at Adrano (n. 55) [Cultraro, 2007], the settlement of Valcorrente at Belpasso (n. 36) [Palio and Turco, 2020], and Scalonazzo at Biancavilla (n. 43) [Privitera et al., 2012].

During this period, the occupation of the Etnean territory became more intense, with a significant increase in the number of settlements on all slopes and at different altitudes, although it is likely that not all are contemporary; they were frequented, perhaps, on a seasonal basis, and were possibly aimed at the systematic exploitation of the resources of the different environments.

Starting from the Final Copper Age, we have evidence of frequented sites at high altitudes, above $1000 \mathrm{~m}$ a.s.l. This involved the extensive occupation of the lava flows of the lower member of the Pietracannone formation (15$3.9 \mathrm{ka}$ BP). These lava flows, characterized by less than a meter-thick layers of soil, were used for agricultural activity. 


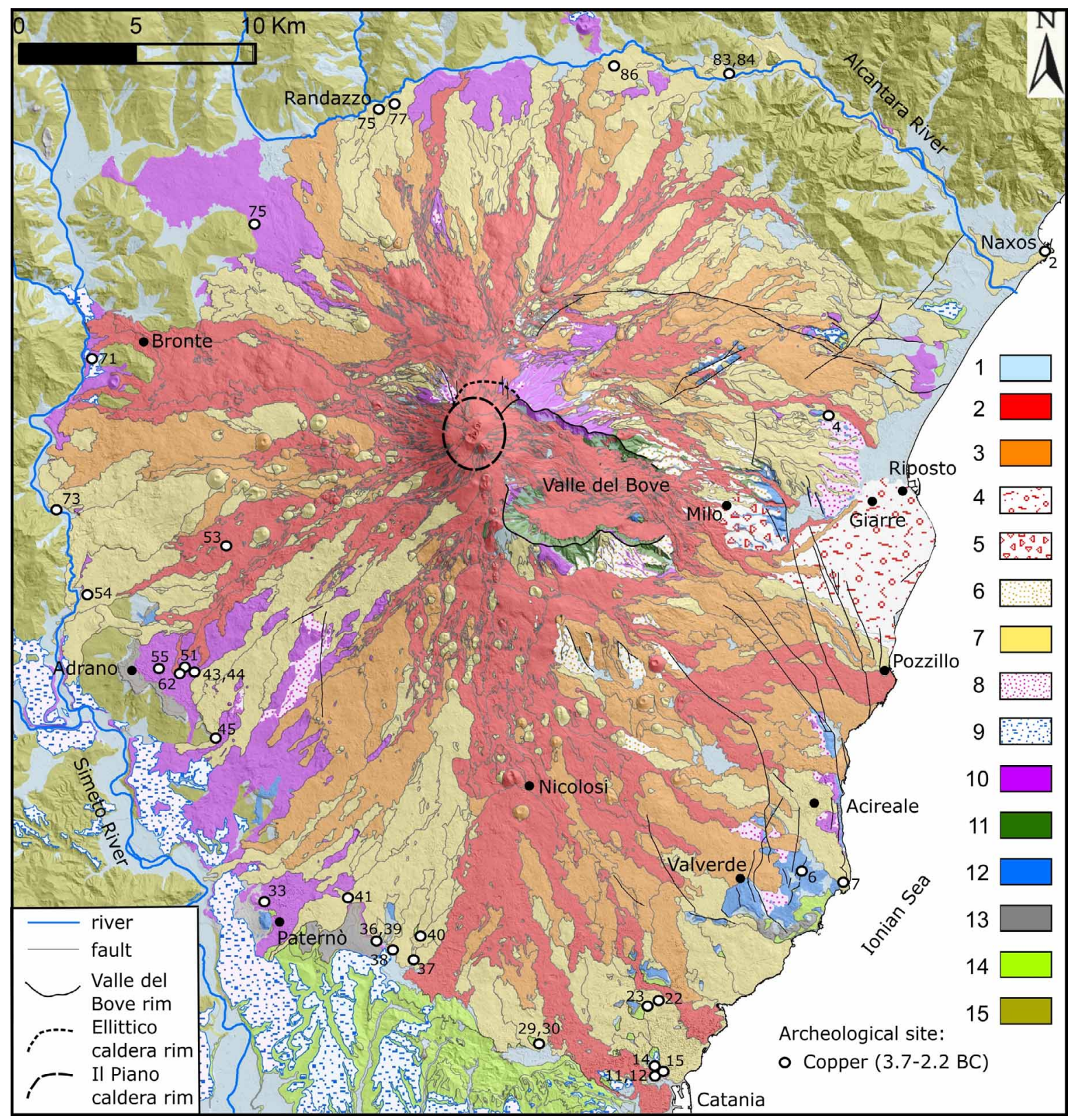

Figure 6. Geological map of Etna volcano modified from Branca et al. (2011a) with the location of the archeological sites of Copper Age (3700-2200 yrs BC). For the legend of the map see Figure 3.

The early lava flows of the Ellittico, Monte La Nave and Fontanelle, were still frequented in the Early Bronze Age along the edge of the Simeto valley and the Saracena stream; the "pahoehoe" lava slabs of the first cited lava were used to build a funerary megalithic spiral structure and other dolmens in the territory of Bronte [Palio and Turco, 2015]. Many of the known sites of this age are caves, which may often have been related to outdoor settlements, with both funerary and ritual function, or, in rarer cases, temporary shelters in high altitude areas, suitable for seasonal activities, such as sheep farming or searching for raw materials like resins (Schadlish Cave: n 80; Grotta delle Femmine: n 90; both on the northern slope) [Privitera, 2014; Mentesana and Fragnoli, 2020].

To this period belong most of the samples dated in the present study (Table 3). They are, for the Late and Final Copper Age, Scalonazzo near Biancavilla (n. 43), and Marca, in the territory of Castiglione (n. 83), both on lava flows of the lower member of Pietracannone formation; at Scalonazzo, where the lowest layers have not yielded datable samples, the earlier sample comes from a Late Copper Age floor level, dated 2874-2621 cal BC; the sample from Marca, outside of the cave, has been dated 2678-2482 cal BC (for the inside of the cave we have a date of 2460-2340 
cal BC). Both datings are similar to those of Venetico excavation, on the Tyrrhenian coast of Sicily [Martinelli 2013; Martinelli, Cannizzaro, Gusmano 2014, 166] and of the Late Copper Age sites in the Tyrrhenian coast of Calabria [Pacciarelli, 2011].

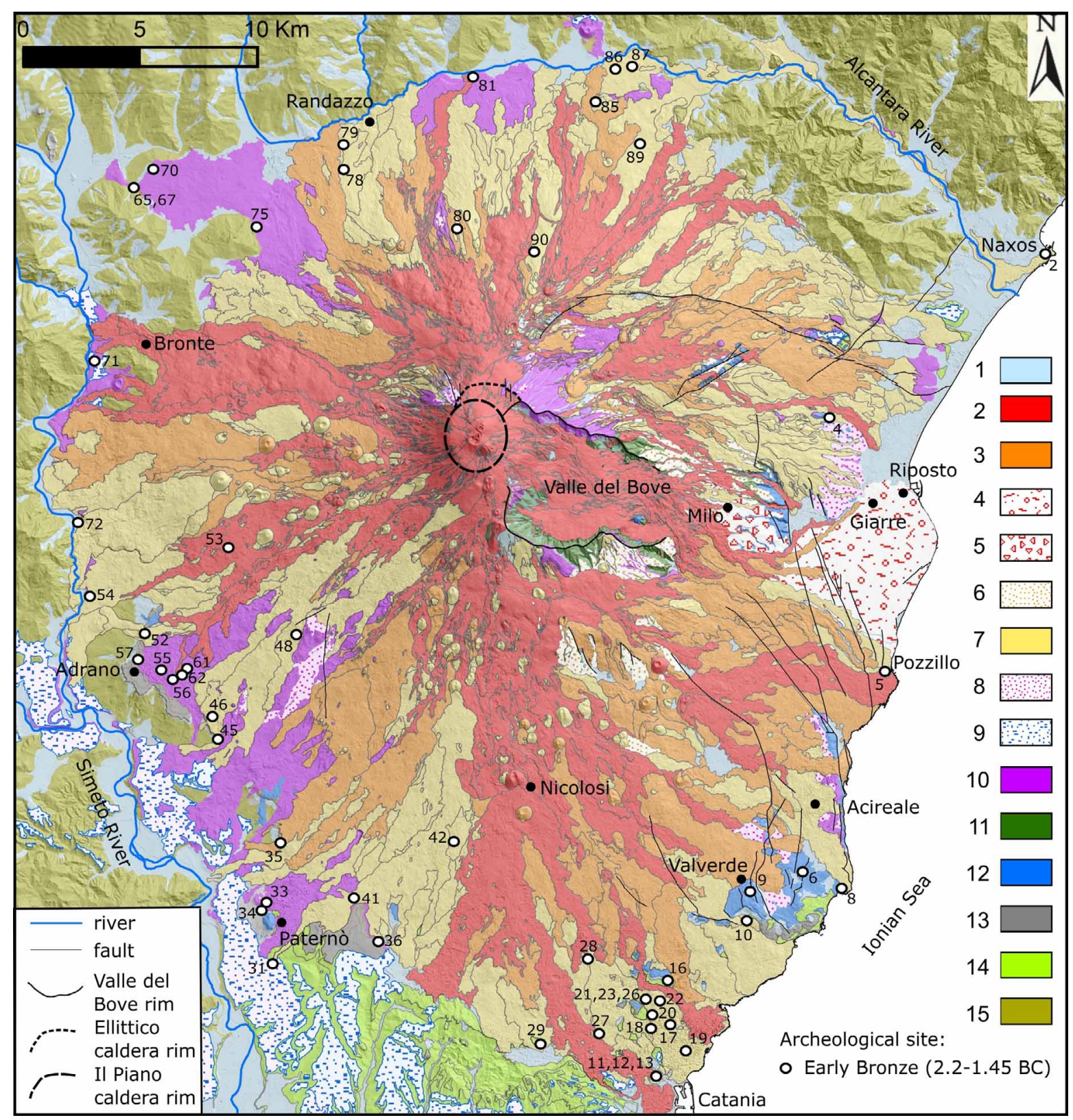

Figure 7. Geological map of Etna volcano modified from Branca et al. (2011a) with the location of the archeological sites of Early Bronze Age (2200-1450 yrs BC). For the legend of the map see Figure 3.

The Early Bronze Age is dated between 2200 and 1450 BC. The two datings obtained from the Petralia cave at Catania (n. 22) and the deposit of contrada Ciarambello at Randazzo (n. 81) both relate to the earlier phase (Table 3), not far from those referred to the end of the Final Copper Age and confirm the demographic growth in the Etnean territory during this period (Figure 7). The dating samples of the last phases of the settlement of Valcorrente (n. 36). refer instead to the final phase of the Early Bronze Age (1600-1450 BC). In the territory of Adrano, a bronze cup, glass and amber beads have been found in the Maccarrone cave (n. 55), of certain Minoan-Mycenaean origin, datable around 1600 BC [Cultraro, 1989]. In any case, the relative scarcity of dates of this last moment of the Early Bronze 


\section{Stefano Branca et al.}

Age will be the object of further and accurate investigations. Among other things, it should be noted that the lava flows, after the explosive event of 3930 \pm 60 yr BP (about 1980 BC), did not preserve traces of human prehistoric settlement, at least until to historical times. This absence could mean a rare frequentation of lava lands because they were too recent and not usable even for grazing. We cannot exclude that many flank eruptions, belonging to the upper member of the Pietracannone formation, could be dated after the end of the Early Bronze Age and therefore covered the sites of this period.

From Middle to the Final Bronze Age (1450-900 BC), the Etnean region underwent a drastic reduction in the number of settlements. No dating has been carried out for these later periods, also because the few known sites have not been investigated recently. However, the general chronology, based on the style and typology of the pottery contexts, could be considered reliable.

The Middle Bronze Age (1450-1250 BC) is attested along the coast especially, more evident than in other parts of Sicily (Figure 8). Sites such as Naxos (n. 2; Procelli, 1983; Lentini,1993-94, 2020), Capo Mulini (n. 8; Tomarchio, 1980), Catania (S. Paolillo: n. 16; Montevergine: n. 11; Barriera: n. 23) [Tanasi, 2010; Privitera, 2010] (Figure 2.12), survived and thrived because they had an important role in the communications between the coast and the hills. The discovery, at $S$. Paolillo, of Mycenaean fragments (TE III A2-B, 1350-1200 BC) [Tanasi, 2010], confirms that these settlements, like those much more important ones of the southeastern and southern coast of Sicily, were part of the trades with the Aegean.

All these sites were near springs and streams or even in a dominant position with excellent visibility of the coast. Probably the population tended to concentrate in larger settlements. It should be noted the abandonment of the territories far from the coast. An exception is the hill of Paternò (n. 32-34), an important site during the Late Bronze Age especially.

Among the caves, which lost their function as a funerary or ceremonial place, only a few in the hills of Catania were frequented (nos. 24-25) [Orsi, 1907], hence the Filiciosa cave of Biancavilla (n. 49) [Cultraro, 1997], where the presence of miniature vases suggests a ritual rather than a funerary use. Regarding the funerary aspects, it is worth noting the tomb in a ravine shaped into a pseudo-rock-cut tomb at Valverde (n. 9) [Branciforti, 1999], without grave goods, from which a sample of human bone has been dated to $3100 \pm 40 \mathrm{BP}$ uncalibrated, which should correspond to a date around $1300 \mathrm{BC}$ (Table 3). Given the small number of sites and their locations, it makes little sense to look for a relationship with lavas. Some are on more recent lava flows than the Ellittico, others on earlier formations. None, as in the last phase of the Early Bronze Age, are on lava flows more recent than the explosive event of $3930 \pm 60 \mathrm{BP}$ (about 1980 BC), as would theoretically be possible.

Many of the Sicilian coastal sites were surrounded by fortifications, probably to avoid incursions from the sea (at Naxos, as at Thapsos, Cannatello, Faraglioni di Ustica). At Naxos, for this purpose, blocks from the same Alcantara lavas, on which the settlement rests, were used [Lentini, 2020].

During the Middle Bronze Age and, furthermore during the following Late and Final Bronze Age (1250-900 BC) (Figure 8), a substantial abandonment of the territory is noted in the Etna area. During these same chronological periods, in other areas of Sicily, large agglomerations with a pastoral economy were founded, such as Pantalica. The documentation, in addition to the scarce evidence of Catania, refers mainly to the area of Paternò (S. Marco, Collina Storica, via S. Caterina: n. 32-34) [Maniscalco, 2012] (Figure 2.13) and perhaps, to the Filiciosa cave, in the territory of Biancavilla, if the pots found also belong to this phase (n. 47) [Cultraro, 1997]. The sporadic finding of bronze axes and a spearhead in wooded areas of Nicolosi and Maletto (Feudo Soprano), above $800 \mathrm{~m}$ a.s.l., could mean that these areas were occasionally frequented for cutting wood and hunting [Cultraro, in press.; Privitera and Turco, in press]. Subsequently, and until the arrival of the Greeks, there was almost a disappearance of human settlements on all the slopes of Etna, including the area of Catania [Frasca, 2010].

\section{Discussion}

Until now, cases of direct overlapping of lava flows on archaeological sites are extremely rare. We only know the cases of Cingalenta and perhaps Trefontane, both near Paternò. Unfortunately, the discovery in Acireale of the Early Bronze Age pottery with evident traces of burning related to the eruptive activity of Etna [Tusa, 1990-91] is not confirmed. The combustion traces on the pottery are not especially meaningful, so it is difficult to attribute to contact with the lava. Furthermore, in this area there are no lava flows from the period after the Early Bronze Age [Branca et al., 2011a]. 


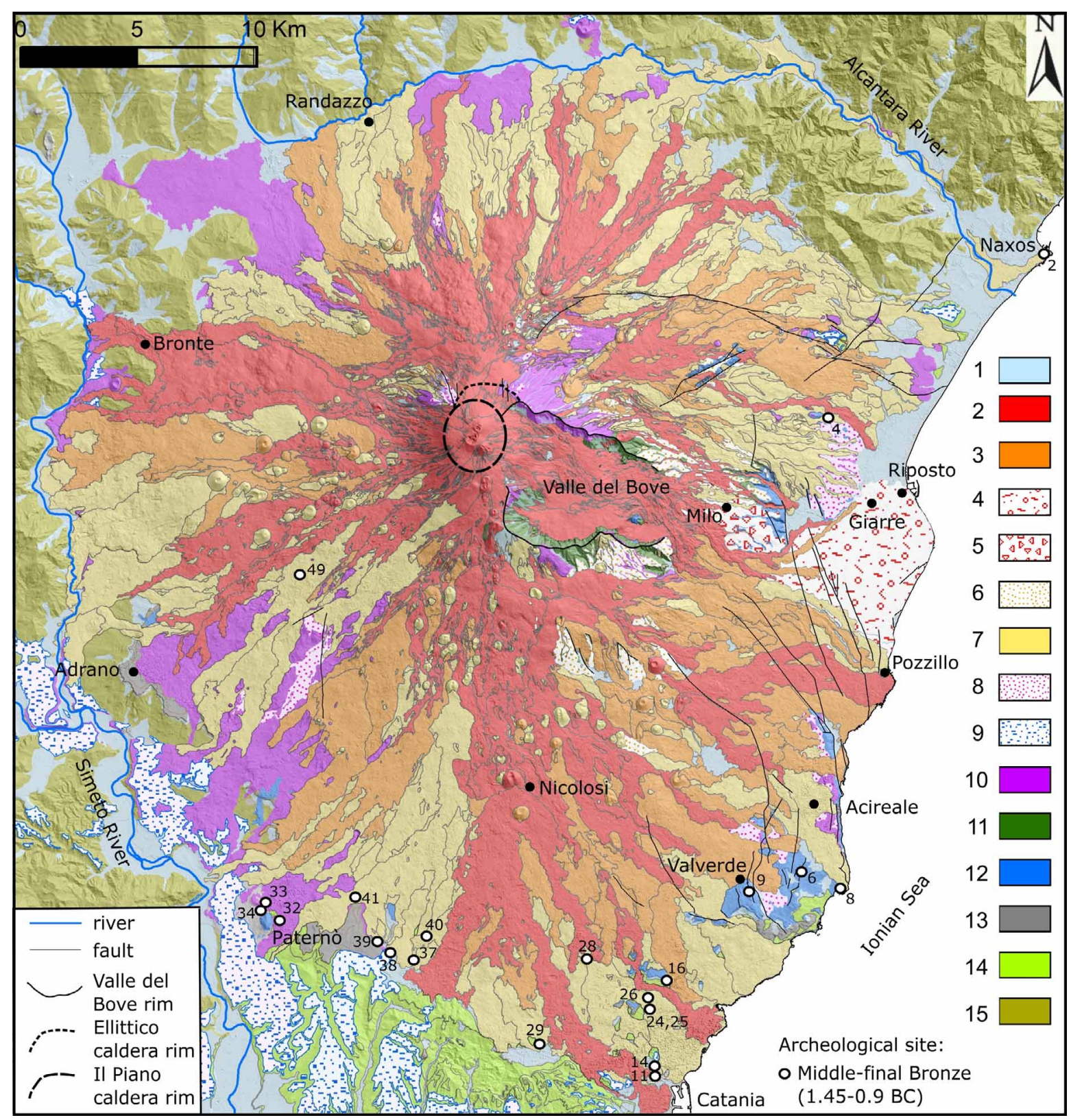

Figure 8. Geological map of Etna volcano modified from Branca et al. (2011a) with the location of the archeological sites of Middle, Late and Final Bronze Age (1450-900 yrs BC). For the legend of the map see Figure 3.

More common are cases of archaeological sites located on the soil covering older flows or inside flow caves that in theory could have been frequented as soon as a lava flow had cooled.

The ten new ${ }^{14} \mathrm{C}$ dates performed for this work significantly enhance the chronological framework of the Etnean area, especially for the Final Copper Age phase. They also confirm the framework of absolute and stratigraphic dating of lavas already known [Branca et al., 2011b]. There are no evident relationships of archaeological sites with explosive events, even though they have been cited in previous bibliography [Cultraro, 1997, 2020]. The only pyroclastic deposit that covered a site frequented in pre- and protohistoric times is that of the historical period (FG tephra layer- $122 \mathrm{BC}$ in Figure 4), found in the site of Valverde, above the remains of the Hellenistic period (IV-III century BC) [Privitera, 2005] and therefore indirectly, above the layers of the Early and Middle Bronze Age. The chronological interval set for the upper member of the Pietracannone formation, 15-3.9 ka BP, is quite wide. It cannot be excluded that some of the lava flows, on which the Middle Neolithic does not appear, might belong to a final phase of this stratigraphic interval (<5000 BC). The only ascertained case is the lava flow of S. Giovanni Galermo-Larmisi that, since recent 


\section{Stefano Branca et al.}

dating, seems to be placed in the middle of the 4th millennium BC (5494-5387 BP) [Magli et al., 2021, Monaco et al., 2000]. This new age determination agrees with the ${ }^{14} \mathrm{C}$ age of a charcoal from Petralia Cave $(5060 \pm 30 \mathrm{BP} ; 3954-3788$ cal BC), recovered near burials of the Final Copper Age (2500 BC) but probably referred to an earlier archaeological phase, attested only by a Piano Conte style clay vessel [for the dating of Piano Conte facies in North -Eastern Sicily and Calabria, see Martinelli, 2001; Pacciarelli, 2011] (Figure 2.5). It can be assumed that this charcoal represents the earliest evidence of frequenting the lava tubes some centuries after the emplacement of the S. Giovanni GalermoLarmisi lava flow that radically modified the morphology of the area forming the present urban district of Catania.

The dates referring to the end of Neolithic (Balze Soprane: n. 69), the Final Copper Age (Marca, Scalonazzo: n. 84, 43) and Early Bronze Age (Petralia Cave, Ciarambello: n. 22, 81) are similar to those of other sites outside the Etnean area and confirm the framework of chronological sequences for this area [Nicoletti, 2015].

From the geological map of the volcano [Branca et al., 2011a], the soils occupied during the Final Copper Age and Early Bronze Age are mostly those covered by lava flows of the lower member of the Pietracannone formation (15$3.9 \mathrm{ka}$ BP). Only in a few cases do we have absolute dates that can restrict the chronological range, but in any case, it is likely that the communities living in these areas sought land whose surface was occupied by soil that was not necessarily very deep, as, for example, the Late Copper Age settlement of Marca, where the soil was extremely shallow. This situation, however, allowed grazing essentially for sheep and goats, as shown by the disposable archaeozoological data, and an agriculture that had to exploit either the deeper basins of the lavas filled with soil (Balze Soprane), or, in a few cases, the adjacent looser and deeper soils, at the edge of the volcano, as is the case of some sites along the course of the Simeto river.

Excluding territories covered by more recent lava flows, the distribution of sites at the different elevations of the volcano may indicate possible seasonal movements up to the medium or high elevations. For example, the lava field called Solicchiata, now dated 5391-5316 cal BC [Branca et al., 2019], has numerous Early Bronze Age sites between 500 and $735 \mathrm{~m}$ a.s.l., mostly caves. Adding, however, the nearby lava flows in the same territory of Castiglione di Sicilia, although of earlier date, settlements are distributed from $390 \mathrm{~m}$ a.s.l. (Marca) to $1600 \mathrm{~m}$ a.s.l. (Grotta delle Femmine), which is the highest known prehistoric site on Etna. This would perhaps testify to the search for special raw materials, such as resins (Mentesana and Fragnoli, 2020), or the seasonal movement of flocks, consistent with the scarcity of water sources or again, possibly, hunting.

As for the lava flows emplaced after the explosive episode of $3930 \pm 60$ BP (about 1980 BC), which would correspond to the end of the Early Bronze Age, as we mentioned before, not a single site has been found. The caves of S. Giovanni Galermo and Via Ota, at Catania (n. 27, 28), seemed to represent an exception, as they are included in the lava flow named S. Giovanni Galermo, recently considered the same as the Larmisi lava flow, and dated with paleomagnetic method at 5494-5387 BP [Magli et al., 2021], that is considerably earlier than when the two caves were frequented.

The low number of sites on Etna between the Late and Final Bronze Age is still surprising. If the sites in question have not been covered by the flows of historical age, a phenomenon which is very widespread on the south-eastern slope, we observe a substantial absence of archaeological evidence related to these periods, except for the area of Paternò, and for sporadic finds at Catania.

A similar issue is the well-known controversy concerning one or more eruptions that, according to Greek-age sources, would have induced the Sikans to abandon eastern Sicily before the arrival of the invading Sikels [Guidoboni et al., 2014]. Contemporary historiographic research has ascertained that the passage of the Italic populations known as Sikels did not occur in the violent ways hypothesized by ancient authors as a sudden ethnic replacement, except in the Aeolian islands, but as a process of progressive infiltration and mixing of different human groups [Albanese Procelli, 2003]. It is also worth noting that the notion of the Etnean volcanic eruptions as the reason for abandoning the eastern area of the island is considered by historians an invention by ancient historiography to justify the conquest of the land by the Greek colonists from the Sicilian communities considered non-native [Militello, 1996].

Nevertheless, it cannot be excluded that among the local populations there remained a muddled memory of eruptions, above all explosive ones, which took place before $1000 \mathrm{BC}$, when the displacements of foreign human groups must have taken place. Although it may seem a coincidence, right at the transition between the Middle and Late Bronze Age (generally dated around $1250 \mathrm{BC}$ ), when the formation of a Sikanian ethnic awareness is hypothesized (La Rosa, 1989), a major explosive eruption [FL tephra layer of Coltelli et al., 2000] occurred around $1200 \mathrm{BC}$ followed by other lesser magnitude explosive events [Del Carlo et al., 2004]. To reiterate, however, none of these explosive events alone could have caused the abandonment of the Etnean territory due to the limited impact on the territory (Figure 4). 


\section{Conclusive remarks}

In this paper, we present for the first time an interdisciplinary study comprising geological and archaeological data that were combined with the aim of defining the history of the human settlements on the Etna region in relation to the eruptive activity. The main results can be summarised in the following points:

The new dates presented in this study, along with those obtained from several sites in recent years, do not conflict with the dates of prehistoric-age lava flows presented in the new geologic map of the volcano and subsequent updating. In some cases, indeed, they help to better constrain the chronological range of same lava flows within the stratigraphic framework of Etna volcano.

The main volcanic events that highly impacted the Etna territory occurred during the passage between Upper Paleolithic and Mesolithic around 13550-13050 BC and then following during the whole Neolithic period as a consequence of the Valle del Bove formation, which radically modified the morphological setting of the eastern flank down to the coast. This explains the absence, on almost the entire Etnean territory, of sites dated between 13000 and $6000 \mathrm{BC}$ and, in general, the scarcity of prehistoric sites on the eastern slope of Etna.

From an archaeological point of view, a lengthy duration of the Late Copper Age (at least from 2800 BC) and the beginning of the Early Bronze Age, already in 2300-2200 BC, concur with the previous data.

For the periods scarcely represented archaeologically in the Etnean territory, such as the Early Copper Age or the Late and Final Bronze Age, a direct connection with explosive eruptions of the volcano is to be excluded due to the limited and local impact of these events, even if it is possible that the memory of a particularly intense explosive eruption in the Final Bronze Age (around 1200 BC) was preserved in the collective memory of indigenous communities until historical times.

With regard to the distribution of known sites, it should be noted that Etna has had, in the last 4000 years, an increase in the number of flank eruptions, and therefore the surfaces covered by recent lava flows are particularly extensive. Below these surfaces, except in exceptional cases, the presence of archaeological sites is not recognizable.

Regarding the dynamics of the settlement, from a topographical viewpoint there are very few sites on the eastern slope of the volcano, all located near the coast or water sources; generally, they arise on very ancient volcanic formations. Excluding the lava flows of historical period, which are fairly extensive in the surroundings of Acireale, it cannot be excluded that some other site may be found below the deep soils, quite common in this area. On the other slopes, human presence from the Neolithic onwards is widespread, even if often found only within caves.

The settlements of the Middle Neolithic period are either on alluvial deposits formed by material of earlier lava flows or on lava flows of the oldest phases of the volcano in sites characterised by favourable conditions for sufficient agricultural production for the subsistence of these communities. Few are found on lava flows of the lower member of Pietracannone formation (15-3.9 ka BP) allowing us to better constrain their stratigraphic ages.

For the Late Neolithic and subsequent phases up to the Early Bronze Age, an increase of the frequentation of all the lava flows of the lower member of the Pietracannone formation (15-3.9 ka BP) is clearly perceptible, while now there are none on the lava flows of the upper member, which are evidently too recent. In general, a development of pastoral activity and working of hard soil seems evident.

The future archaeological research can therefore concentrate, except for the occasional findings below the flows, as in the case of Trefontane or Cingalenta di Paternò, on the lavas of this last period, especially where there are caves. Thus, in the territory of Randazzo, at 1300 m altitude, the recent discovery of the Schandlish cave, in the lavas of the lower member of Pietracannone formation, would confirm this observation. Consequently, the relative density of sites between $700 \mathrm{~m}$ and $1600 \mathrm{~m}$ a.s.l. on such lavas might suggest the analogous density in the lands covered by the lavas of the last four millennia.

Acknowledgements. Thanks are due to the anonymous reviewers for their useful comments. The researcher was supported by Dipartimento Protezione Civile "Conv. All. A" funds. 


\section{Stefano Branca et al.}

\section{References}

Agodi, S. (2010). Testimonianze della Tarda Età del Rame dal vano 8 dell'ex monastero dei Benedettini, Tra lava e mare. Contributi all'archaiologhia di Catania, M.G. Branciforti and V. La Rosa (Editors), Catania, 63-71.

Albanese Procelli, R.M. (2003). Sicani, Siculi ed Elimi, Milano.

Alberghina, F. and E. Procelli (2002). Rinvenimenti archeologici della grotta Domenico Conti nel territorio di S. Gregorio, Sicilia Archeologica, 35, 2002, 113-123.

Amari S. (2005). Materiali per la datazione dello scavo condotto all'interno dell'ex Reclusorio della Purità a Catania, Megalai Nesoi. Studi Dedicati a Giovanni Rizza per il Suo Ottantesimo Compleanno, R. Gigli (Editor), Catania, 60-72.

Arrabbito, S. and S. Muratore (2020). Il territorio di Belpasso (CT) nella preistoria: le prospezioni del 2013, Vivere all'ombra del Vulcano. L'insediamento di Valcorrente di Belpasso nel contesto degli studi sulla preistoria siciliana tra il IV e la prima metà del II millennio a.C., O. Palio, S. Todaro and M. Turco (Editors), 19-29.

Azzaro, R., S. Branca, K. Gwinner and M. Coltelli (2012). The volcano-tectonic map of Etna volcano, 1:100,000 scale: morphotectonic analysis from high-resolution DEM integrated with geologic, active faulting and seismotectonic data, Ital. J. Geosci., 131 (1), 153-170.

Baldini, L.R., G. Cassataro, U. Longo and E. Recami (1976). Recenti scoperte sul paleolitico siciliano, Natura, 67, 125216.

Basile, G. (1891). Villaggio trogloditico dell'epoca neolitica esistente a nord della città di Catania, Bull. Pal. It., 17, 112-114.

Bernabò Brea, L. (1958). La Sicilia prima dei Greci, Milano.

Bernabò Brea, L. (1965). Segnalazione di rinvenimenti paleolitici in Sicilia, Bull. Pal. It.,74, 7-22.

Branca, S. (2003). Geological and geomorphological evolution of the Etna volcano NE flank and relationships between lava flow invasions and erosional processes in the Alcantara Valley (Italy), Geomorphology, 53, 247261.

Branca S. and V. Ferrara (2001). An example of river pattern evolution produced during the lateral growth of a central polygenic volcano: the case of the Alcantara river system, Mt Etna (Italy), Catena, 45/2, 85-102.

Branca, S. and V. Ferrara (2013). The morphostructural setting of Mount Etna sedimentary basement (Italy): Implications for the geometry and volume of the volcano and its flank instability, Tectonophysics, 586, 46-64.

Branca, S. and T. Abate (2019). Current knowledge of Etna's flank eruptions (Italy) occurring over the past 2500 years. From the iconographies of the XVII century to modern geological cartography, Journal of Volcanology and Geothermal Research, 385, 159-178.

Branca, S., M.G. Branciforti, A.F. Chiavetta, R.A. Corsaro (2016). The geology of 2nd century AD amphitheater area of Catania, Italy: historical eruptions affecting the urban district, Geoarchaeology, 31, 3-16.

Branca, S., M. Coltelli, G. Groppelli and F. Lentini (2011a). Geological map of Etna Volcano 1:50.000 scale, It. J. Geosci., 1303, 265-291.

Branca S., M. Coltelli and G. Groppelli (2011b). Geological evolution of a complex basaltic stratovolcano: Mount Etna, Italy, Ital. J. Geosci., 130 (3), 306-317.

Branca, S., M. Coltelli and G. Groppelli (2015). Carta geologica del Vulcano Etna (Editors), Memorie descrittive della Carta geologica d'Italia, 98, Firenze.

Branca, S., G. De Guidi, G. Lanzafame and C. Monaco (2014). Holocene vertical deformation along the coastal sector of Mt. Etna volcano (eastern Sicily, Italy): Implications on the time-space constrains of the volcano lateral sliding, J. Geodyn., 82, 194-203.

Branca S., M. Coltelli and P. Del Carlo (2016). $\mathrm{C}^{14}$ dating of the Milo debris deposit at Etna volcano (Italy): new age constraints for the Valle del Bove formation, Rend. Online Soc. Geol. It., 40, 630

Branciforti, M.G. (1999). Siti e insediamenti nella regione etnea, Magna Grecia e Sicilia, M. Barra Bagnasco, E. De Miro and A. Pinzone (Editors), Soveria Mannelli (Catanzaro), 241-258.

Branciforti, M.G. (2006). L’area archeologica di Santa Venera al Pozzo-Acium: antiquarium, Palermo.

Cafici, C. (1914). Stazioni preistoriche di Tre Fontane e Poggio Rosso in territorio di Paternò (provincia di Catania), Monumenti Antichi dei Lincei, 23, 485-540.

Cafici, C. (1920). La stazione neolitica di Fontane di Pepe (Belpasso) e la civiltà di Stentinello in Sicilia e sul versante adriatico dell'Italia meridionale, Palermo. 
Calvari, S., L.W. Tanner and G. Groppelli (1998). Debris-avalanche deposits of the Milo Lahar sequence and the opening of the Valle del Bove on Etna volcano (Italy), J. Volcanol. Geotherm. Res., 87, 193-209.

Calvari, S., L.H. Tanner, G. Groppelli and G. Norini (2004). A comprehensive model for the opening of the Valle del Bove depression and hazard evaluation for the eastern flank of Etna volcano, A. Bonaccorso, S. Calvari, M. Coltelli, C. Del Negro, and S. Falsaperla (Editors), Etna Volcano Laboratory, Geophys. Monogr. 143, 65-75. Washington, DC: American Geophysical Union.

Cavalier, M. and M. Cultraro (2009). L'insediamento eneolitico sul Poggio dell'Aquila (Adrano): risultati preliminari, Tra Etna e Simeto. La ricerca archeologica ad Adrano e il suo territorio, G. Lamagna (Editor), Giarre (Catania), 49-64.

Coltelli, M., P. Del Carlo and L. Vezzoli (1998). The discovery of a Plinian basaltic eruption of Roman age at Etna volcano, Italy, Geology, 26, 1095-1098.

Coltelli, M., P. Del Carlo and L. Vezzoli (2000). Stratigraphic constraints for explosive activity in the past 100 ka at Etna Volcano, Italy, Int. J. Earth Sciences, 89, 665-677.

Coltelli M., P. Del Carlo, M. Pompilio, and L. Vezzoli (2005). Explosive eruption of a picrite: The 3930 BP subplinian eruption of Etna volcano (Italy), Geophys. Res. Lett., 32, 1-4.

Consoli, A. (1988-89). Bronte-Maletto: prima esplorazione e saggi di scavo archeologico nelle contrade Balze Soprane, S. Venera, Edera e Tartaraci, BCA Sicilia, IX-X, 3, 74-79.

Cultraro, M. (1988). Distribuzione dell'Eneolitico nella fascia etnea meridionale e sui margini della Piana di Catania, L’Età del Rame in Europa, Atti del Congresso Internazionale, Viareggio 1987, Rassegna di Archeologia, 7, Firenze, 550-551.

Cultraro, M. (1989). Il castellucciano etneo nel quadro dei rapporti tra Sicilia, penisola italiana ed Egeo nei secc. XVI e XV a.C., Sileno, XV, 259-282.

Cultraro, M. (1997). The Cyclops before the Greeks: The Emergence of Civilization in the Etna Region, in B. De Vivo, M. Contini, C. Albore Livadie (Editors), Volcanism and Archaeology in Mediterranean Area, Trivandrum, 129148.

Cultraro, M. (2007). La regione etnea fra Neolitico ed antica età del Bronzo: dinamiche culturali e sviluppo cronotipologico, In Ima Tartara. Preistoria e leggenda delle grotte etnee, F. Privitera and V. La Rosa (Editors), Palermo, 57-79.

Cultraro, M. (2014). Catania prima di Evarco. Per una carta archeologica delle evidenze preistoriche nell'area urbana, Topografia Antica, 3, 39-74.

Cultraro, M. (2016). Catania prima dei greci, Catania antica. La carta archeologica, E. Tortorici (Editor), Roma, 237266.

Cultraro, M. (2019). Tra l'Etna e le Madonie: la frequentazione dei siti ad alta quota nella pre-protostoria della Sicilia, Preistoria e protostoria in ambiente montano: scoperte e ricerca territoriale, tutela e valorizzazione, F. Rubat Borel (Editor), Firenze, 75-77.

Cultraro, M. (2020). Il Neolitico nella media valle del Simeto: sequenze stratigrafiche, modelli di insediamento e dinamiche culturali, Vivere all'ombra del Vulcano. L'insediamento di Valcorrente di Belpasso nel contesto degli studi sulla preistoria siciliana tra il IV e la prima metà del II millennio a.C., O. Palio, S. Todaro and M. Turco (Editors), 177-190.

De Beni E., S. Branca, M. Coltelli, G. Groppelli and J. Wijbrans (2011). 39Ar/40Ar isotopic dating of Etna volcanic succession, Ital. J. Geosci., 130, 3, 292-305, DOI: 10.3301/IJG.2011.14.

De Fiore, O. (1921). Materiali archeologici della regione etnea e loro rapporti con eruzioni e bradisismi, Miscellanea di studi sicelioti e italioti in onore di Paolo Orsi, Catania, 84-99.

Del Carlo, P. and M. Pompilio (2004). The relationship between volatile content and the eruptive style of basaltic magma: the Etna case, J. Geophys., 47, 1-10.

Di Vita, A. (1955). Catania, necropoli della prima età del Bronzo. Via Novalucello, Fasti Archeologici, X, 1955 (1957), 200.

Finné M., K. Holmgren, H.S. Sundqvist, E. Weiberg, and M. Lindblom (2011). Climate in the eastern Mediterranean, and adjacent regions, during the past 6000 years: A review, Journ. Arch. Sc., 38, 3153-3173.

Frasca, M. (2010). Katane. Il periodo protostorico e le prime fasi della colonia, Tra lava e mare. Contributi all'archaiologhia di Catania, M.G. Branciforti and V. La Rosa (Editors), Catania, 101-108.

Giannitrapani, E. (2020a). Indagini geoarcheologiche e paleoambientali per la ricostruzione dei paesaggi di età 


\section{Stefano Branca et al.}

preistorica nella Sicilia centrale. I casi studio del Riparo di Contrada S. Tommaso (Enna) e Case Bastione (Villarosa), Geologia Tecnica \& Ambientale 1, 47-64.

Giannitrapani, E. (2020b). Continuity or change? Il passaggio dal Neolitico all'età del Rame nella Sicilia centrale: teoria sociale, modi di produzione e cultura materiale, Vivere all'ombra del Vulcano. L'insediamento di Valcorrente di Belpasso nel contesto degli studi sulla preistoria siciliana tra il IV e la prima metà del II millennio a.C., O. Palio, S. Todaro and M. Turco (Editors), 139-176.

Guerri, E. (1990). Nuovi metodi di indagine: sepoltura stentinelliana in località Fontanazza (Adrano), Annali Museo Civico di Rovereto, Supplemento vol. 6, 223-228.

Guidoboni E., C. Ciuccarelli, D. Mariotti, A. Comastri and M.G. Bianchi (2014), L'Etna nella storia. Catalogo delle eruzioni dall'antichità alla fine del XVII sec., Bologna.

Gullì, D. and F. Terrasi (2020). Nuove datazioni radiometriche da siti del territorio agrigentino e proposte per una sistematizzazione della cronologia dall'età del Rame all'età del Bronzo, Vivere all'ombra del Vulcano. L'insediamento di Valcorrente di Belpasso nel contesto degli studi sulla preistoria siciliana tra il IV e la prima metà del II millennio a.C., O. Palio, S. Todaro and M. Turco (Editors), 190-206.

La Rosa, V. (1985). Paolo Orsi e la preistoria della Sicilia, Annali del Museo Civico di Rovereto 1, 5-21.

La Rosa, V. (1989). Le popolazioni della Sicilia. Sicani, Siculi, Elimi, Italia omnium terrarum parents, Milano, 2-110.

Lamagna, G., Neri, N.F., 2015, Il Museo Regionale di Adrano. Le collezioni archeologiche, Palermo.

Lentini, M.C. (1993-94). Nuove esplorazioni a Naxos (scavi 1989-1994), Kokalos, XXXIX-XL, 1001-1026.

Lentini, M.C. (2020). Le cinte murarie di Naxos di Sicilia, in Fortificazioni e società nel Mediterraneo occidentale, L.M. Caliò, G.M. Gierogiannis and M. Kopsacheili (Editors), Roma, 39-54.

Lisi S., F. Mallegni and F. Privitera (2009). Paleobiologia di alcuni neolitici dal sito Contrada Balze Soprane a Bronte (CT), Archivio per l'Etnologia e l'Antropologia, CXXXIX, 43-64.

Magli A., S. Branca, G. Giordano, F. Speranza, G. Risica and G. Siravo (2021). Paleomagnetic dating of prehistoric lava flows from the urban district of Catania (Etna volcano, Italy), GSA Bulletin, https://doi.org/10.1130/B36026.1.

Magro, M.T. and I. Vacirca (2017). Monte S. Paolillo, Catania, Notiziario di Preistoria e Protostoria, 4, III, 84-86.

Maniscalco, L. (2000). Il neolitico attorno alla piana di Catania. L'insediamento preistorico presso le Salinelle di S. Marco (Paternò), La Neolitizzazione tra Oriente e Occidente, A. Pessina and G. Muscio (Editors), Udine, 489507.

Maniscalco, L. (2009). Il Neolitico nella Valle del Simeto, Tra Etna e Simeto, La ricerca archeologica ad Adrano e nel suo territorio, G. Lamagna (Editor), Catania, 27-47.

Maniscalco, L. (2012). Il museo Gaetano Savasta e le aree archeologiche di Paternò, Palermo.

Maniscalco, L. (2019), Aspetti dell'età del Bronzo Recente nel territorio di Paternò, Sicilia Antiqua, 16, 131-138.

Martinelli, M.C. (2001). L'insediamento neo-eneolitico di Camaro, Da Zancle a Messina: un percorso archeologico attraverso gli scavi, II, G.M. Bacci, G. Tigano (Editors), 169-181.

Martinelli, M.C. (2013). Cronologia assoluta della tarda età del rame nella Sicilia orientale tirrenica e Isole Eolie, Cronologia assoluta e relativa dell'età del rame in Italia, D. Cocchi Genick (Editor), Atti dell'incontro di studi, Università di Verona 25 giugno 2013, Verona, 192-193.

Martinelli, M.C., F. Cannizzaro and M. Gusmano (2014). Considerazioni sulla facies di Malpasso nella cuspide orientale della Sicilia e nelle isole Eolie, Rivista di Scienze Preistoriche, LXIV, Firenze, 151-192.

Mentesana, R. and P. Fragnoli (2020). The role of ceramic analyses in shaping our understanding of the cultural landscapes of protohistoric Sicily and the Aeolian islands, Journal of Archaeological Science: Reports, 30, 19.

Messina Sluga, G. (1971). Motivi figurativi della ceramica castellucciana, Cronache di Archeologia, X, 7-15.

Militello, P. (1996). I Siculi fra tradizione storica ed archeologia, Civiltà indigene e città greche nella regione iblea, L. Guzzardi (Editor), Ragusa, 43-58.

Monaco, C., S. Catalano, G. De Guidi, S. Gresta, H. Langer and L. Tortorici (2000). The geological map of the urban area of Catania (eastern Sicily): morphotectonic and seismotectonic implications, Memorie Società Geologica Italiana, 55, 425-438.

Nicoletti, F. (2015). L'acropoli di Catania nella preistoria, in Catania Antica. Nuove prospettive di ricerca, F. Nicoletti (Editor), 33-98.

Nobile, P. (1975). Grotta dei Balzi Superiori (Randazzo), Rivista di Scienze Preistoriche, XXX, 391-392.

Orsi, P. (1890). Stazione neolitica di Stentinello (Siracusa), Bull. Pal. It., 16, 177-200 
Orsi, P. (1907). Necropoli e stazioni sicule di transizione. Caverne di abitazione a Barriera (Catania), Bull. Pal. It., 33, 53-99.

Orsi, P. (1930-31). Abitazioni e sepolcri siculi di Biancavilla entro caverne di lava, Bull. Pal. It., 50-51, 134-147

Pacciarelli, M. (2011). L'eneolitico della Calabria tirrenica: nuovi dati sull'articolazione cronoculturale, Origini, XXXIII, 5, 249-302.

Palio, O. and M. Turco (2015a). Una struttura di combustione del Neolitico in contrada Balze Soprane di Bronte (CT), L'acqua la roccia e l'uomo. Lago Gurrida e Sciare di Santa Venera, A. Puglisi and M. Turco (Editors), Nicolosi, 76-81.

Palio, O. and M. Turco (2015b). La struttura megalitica della contrada Balze Soprane di Bronte (Catania), Lacqua la roccia e l'uomo. Lago Gurrida e Sciare di Santa Venera, A. Puglisi and M. Turco (Editors), Nicolosi, 82-85.

Palio, O. and M. Turco (2015c). Strutture megalitiche nell'area etnea (Bronte, Prov. di Catania), Not. Preist. Prot., 2.II, 49-51.

Palio, O. and M. Turco (2020). Il sito di Valcorrente e le sue fasi, Vivere all'ombra del Vulcano. L'insediamento di Valcorrente di Belpasso nel contesto degli studi sulla preistoria siciliana tra il IV e la prima metà del II millennio a.C., O. Palio, S. Todaro and M. Turco (Editors), 31-51.

Poli Marchese, E. (1991). Piante e fiori dell'Etna, Palermo.

Poli Marchese, E., G. Maugeri and G. Ronsisvalle (1981). Carta della vegetazione dell'Etna, Roma.

Privitera, F. (1988-89). Valverde: saggi di scavo in contrada Casalrosato, BCA Sicilia, 80-83.

Privitera, F. (1991-92). Castiglione di Sicilia, contrada Marca: Grotta sepolcrale della tarda età del Rame e del Bronzo antico, BCA Sicilia, 21-25.

Privitera, F. (2005), Linsediamento di Montedoro-Casalrosato (Valverde), Dall'Alcantara agli Iblei. La ricerca archeologica in provincia di Catania, F. Privitera, U. Spigo (Editors), Palermo, 85-88.

Privitera, F. (2007a), Le grotte dell'Etna nella preistoria, In Ima Tartara. Preistoria e leggenda delle grotte etnee F. Privitera and F. La Rosa (Editors), Palermo, 91-117

Privitera, F. (2007b). Il territorio di Bronte: le grotte Tartaraci, Maniace e Balze Soprane, In Ima Tartara. Preistoria e leggenda delle grotte etnee F. Privitera and F. La Rosa (Editors), Palermo, 205-208.

Privitera, F. (2008). Oltre Francavilla: la Valle dell'Alcantara nell'Antichità, Francavilla di Sicilia. L'anonimo centro di età greca. L'area archeologica e l'Antiquarium, U. Spigo (Editor), Soveria Mannelli (Catanzaro), 23 -36.

Privitera, F. (2010). I disiecta membra delle età più antiche: l'area urbana fra Neolitico e Bronzo Medio, Tra lava e Mare: contributi all'archaiologhìa di Catania, M.G. Branciforti and V. La Rosa (Editors), Catania, 45-62.

Privitera, F. (2012). Necropoli tardo-neolitica in Contrada Balze Soprane di Bronte (CT), Atti della XLI Riunione Scientifica dell'Istituto Italiano di Preistoria e Protostoria, Firenze, 543-556.

Privitera, F. (2014). Caves and environment: the case of Etna, From cave to dolmen. Ritual and symbolic aspects in the prehistory between Sciacca, Sicily and the central Mediterranean, D. Gullì (Editor), Oxford, 151-159.

Privitera, F. (2015). Frammenti preistorici dallo scavo dell'abside della basilichetta, La Nunziatella sopra Mascali, G. Buda (Editor), Palermo, 125-137.

Privitera, F. (2018). L'incontro necessario tra vulcanologia e archeologia. L'eruzione dell'Etna del 122 a.C. e le sue testimonianze archeologiche, Gymnasium. Annuario per il centrotrentesimo anniversario del Ginnasio, P. Daniele (Editor), Giarre, 147-160.

Privitera, F. (2020). Un pithos dell'età del Bronzo dal territorio di Randazzo, Cronache di Archeologia, 39, 8-19.

Privitera, F. and V. La Rosa (2007). Editors, In Ima Tartara. Preistoria e leggenda delle grotte etnee, Palermo.

Privitera, F. and M.R. Grasso (2012). Riflessioni sul contesto territoriale antico, Torre Rossa: la riscoperta di un sito archeologico a Fiumefreddo di Sicilia, Fiumefreddo di Sicilia (CT), G. Buda, M.R. Grasso, F. Privitera (Editors), 87-93.

Privitera, F., F. Alberghina and M. Turco (2012). Recenti ricerche nel versante sud-occidentale dell'Etna: Belpasso e Biancavilla, Atti della XLI Riunione Scientifica dell'Istituto Italiano di Preistoria e Protostoria, Firenze, 709717.

Privitera, F. and M. Turco (2019). Contrada Ciarambello, Randazzo (CT), Not. Preist. Prot., II, 59-61.

Procelli, E. (1983). Naxos preellenica. Le culture e i materiali dal neolitico all'età del ferro nella penisola di Schisò, Cronache di Archeologia, 22, 9-82.

Procelli, E. (1989). La grotta dei monaci. Stazione dell'età del rame presso Castelmola (Taormina), Sicilia Archeologica, 71, XXII, 41-50. 


\section{Stefano Branca et al.}

Procelli, E. (1992). Appunti per una topografia di Catania pregreca, Kokalos, XXXVIII, 69-78.

Procelli, E. (2000). Naxos pre-protostorica. Considerazioni 10 anni dopo, Damarato, Studi in onore di P. Pelagatti, Milano, 25-27.

Procelli, E. (2007). Il territorio di Catania: le grotte di Barriera, In Ima Tartara. Preistoria e leggenda delle grotte etnee, F. Privitera, and V. La Rosa (Editors), Palermo, 225-229.

Recami, E., C. Mignosa and R. Baldini (1983). Nuovo contributo sulla preistoria della Sicilia, Sicilia Archeologica, 5253, XIV, 45-82.

Recupero, G. (1815). Storia naturale e generale dell'Etna, Catania (Ristampa Anastatica, Catania 1983).

Soraci, C. (2004). L'Etna e le Eolie. L'emergenza vulcani e i provvedimenti messi in atto dal governo romano, Quaderni Catanesi di studi antichi e medievali 3, 447-474.

Spigo, U. (1986). La civiltà rupestre a Lentini e nella provincia di Catania, La Sicilia rupestre nel contesto delle civiltà mediterranee (Atti del Convegno, 1981), D. C. Fonseca (Editor), Galatina (Lecce), 271-282.

Tanasi, D. (2010). Gli scavi di Monte S. Paolillo e le presenze di tipo egeo nel territorio di Catania, Tra lava e Mare: contributi all'archaiologhìa di Catania, M.G. Branciforti and V. La Rosa (Editors), Catania, 81-94.

Tanasi, D. (2015), La storia di due colline: l'area della città di Catania nell'età del Bronzo medio, Catania antica. Nuove prospettive di ricerca, F. Nicoletti (Editor), Palermo, 143-162.

Tanguy, J.C., M. Condomines, S. Branca, S. La Delfa, M. Coltelli (2012). New archaeomagnetic ${ }^{236}{ }^{2 a-}{ }^{230}$ Th dating of recent lavas for the geological map of Etna volcano, Ital. J. Geosci., 131(2), 241-257.

Tinè, S. (1960-1961). Giacimenti dell'età del rame in Sicilia e la cultura tipo “Conca d'Oro”, Bull. Pal. It., 13, 133-151.

Tomarchio, G. (1980). Il tempietto romano e i resti neolitici di Capomulini, Memorie e rendiconti dell'Accademia di Scienze e Lettere e Belle Arti degli Zelanti e dei Dafnici, II, X, 537-550.

Tusa, S. (1990-91). Intervento, Kokalos, XXXVI-XXXVII, 301-303.

*CORRESPONDING AUTHOR: Stefano BRANCA,

Istituto Nazionale di Geofisica e Vulcanologia, Osservatorio Etneo-Sezione di Catania, e-mail: stefano.branca@ingv.it

(c) 2021 the Author(s). All rights reserved. 
Prehistoric human presence on Mount Etna 